\title{
Variations in global methane sources and sinks during 1910-2010
}

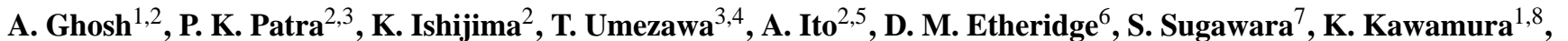
J. B. Miller ${ }^{9,10}$, E. J. Dlugokencky ${ }^{9}$, P. B. Krummel ${ }^{6}$, P. J. Fraser ${ }^{6}$, L. P. Steele ${ }^{6}$, R. L. Langenfelds ${ }^{6}$, C. M. Trudinger ${ }^{6}$, J. W. C. White ${ }^{11}$, B. Vaughn ${ }^{11}$, T. Saeki ${ }^{2}$, S. Aoki ${ }^{3}$, and T. Nakazawa ${ }^{3}$

${ }^{1}$ National Institute for Polar Research, Tokyo, Japan

${ }^{2}$ Department of Environmental Geochemical Cycle Research, JAMSTEC, Yokohama, Japan

${ }^{3}$ Center for Atmospheric and Oceanic Studies, Tohoku University, Sendai, Japan

${ }^{4}$ Max-Planck Institute for Chemistry, Mainz, Germany

${ }^{5}$ National Institute for Environmental Studies, Tsukuba, Japan

${ }^{6}$ CSIRO Oceans and Atmosphere Flagship, Aspendale, Victoria, Australia

${ }^{7}$ Miyagi University of Education, Sendai, Japan

${ }^{8}$ Department of Biogeochemistry, JAMSTEC, Yokosuka, Japan

${ }^{9}$ NOAA Earth System Research Laboratory, Boulder, Colorado, USA

${ }^{10}$ CIRES, University of Colorado, Boulder, Colorado, USA

${ }^{11}$ INSTAAR, University of Colorado, Boulder, Colorado, USA

Correspondence to: A. Ghosh (arindamgr@gmail.com) and P. K. Patra (prabir@jamstec.go.jp)

Received: 17 October 2014 - Published in Atmos. Chem. Phys. Discuss.: 5 November 2014

Revised: 15 February 2015 - Accepted: 24 February 2015 - Published: 9 March 2015

\begin{abstract}
Atmospheric methane $\left(\mathrm{CH}_{4}\right)$ increased from $\sim 900 \mathrm{ppb}$ (parts per billion, or nanomoles per mole of dry air) in 1900 to $\sim 1800 \mathrm{ppb}$ in 2010 at a rate unprecedented in any observational records. However, the contributions of the various methane sources and sinks to the $\mathrm{CH}_{4}$ increase are poorly understood. Here we use initial emissions from bottom-up inventories for anthropogenic sources, emissions from wetlands and rice paddies simulated by a terrestrial biogeochemical model, and an atmospheric general circulation model (AGCM)-based chemistry-transport model (i.e. ACTM) to simulate atmospheric $\mathrm{CH}_{4}$ concentrations for 1910-2010. The ACTM simulations are compared with the $\mathrm{CH}_{4}$ concentration records reconstructed from Antarctic and Arctic ice cores and firn air samples, and from direct measurements since the 1980s at multiple sites around the globe. The differences between ACTM simulations and observed $\mathrm{CH}_{4}$ concentrations are minimized to optimize the global total emissions using a mass balance calculation. During 1910-2010, the global total $\mathrm{CH}_{4}$ emission doubled from $\sim 290$ to $\sim 580 \mathrm{Tg} \mathrm{yr}^{-1}$. Compared to optimized emission, the bottom-up emission data set underestimates the rate of change of global total $\mathrm{CH}_{4}$ emissions by $\sim 30 \%$ during the high growth period of 1940-1990, while it overestimates by
\end{abstract}

$\sim 380 \%$ during the low growth period of 1990-2010. Further, using the $\mathrm{CH}_{4}$ stable carbon isotopic data $\left(\delta^{13} \mathrm{C}\right)$, we attribute the emission increase during 1940-1990 primarily to enhancement of biomass burning. The total lifetime of $\mathrm{CH}_{4}$ shortened from 9.4 yr during 1910-1919 to $9 \mathrm{yr}$ during 20002009 by the combined effect of the increasing abundance of atomic chlorine radicals $(\mathrm{Cl})$ and increases in average air temperature. We show that changes of $\mathrm{CH}_{4}$ loss rate due to increased tropospheric air temperature and $\mathrm{CH}_{4}$ loss due to $\mathrm{Cl}$ in the stratosphere are important sources of uncertainty to more accurately estimate the global $\mathrm{CH}_{4}$ budget from $\delta^{13} \mathrm{C}$ observations.

\section{Introduction}

Methane $\left(\mathrm{CH}_{4}\right)$, the second most important anthropogenic greenhouse gas, plays an important role in the chemical and radiative balances in the Earth's atmosphere. Due to its main removal by reaction with hydroxyl $(\mathrm{OH})$ radical, which is a major atmospheric oxidant, $\mathrm{CH}_{4}$ actively participates in tropospheric air-pollution chemistry. In the stratosphere, $\mathrm{CH}_{4}$ is the predominant source of water vapour (Jones and 
Pyle, 1984) and is the primary sink for chlorine radicals (Cicerone and Oremland, 1988). The global warming potential (GWP) of $\mathrm{CH}_{4}$ is 28 over a time horizon of 100 years (Myhre et al., 2013). Methane is released into the atmosphere from both anthropogenic and natural sources (Patra et al., 2011; Kirschke et al., 2013; and references therein). The 2010 concentration of $\mathrm{CH}_{4}(\sim 1800 \mathrm{ppb})$ is unprecedented over at least the past 800000 years (Loulergue et al., 2008). Measurements of $\mathrm{CH}_{4}$ in air bubbles trapped in Antarctic and Greenland ice sheets suggest that after a very slow increase (average rate of $\sim 0.04 \mathrm{ppbyr}^{-1}$ ) during preindustrial times (1-1750 AD), $\mathrm{CH}_{4}$ concentrations have increased rapidly (average rate of $\sim 4 \mathrm{ppb} \mathrm{yr}^{-1}$ during 1750-1990 AD) until the early 1990s (Rasmussen and Khalil, 1984; Etheridge et al., 1998; Nakazawa et al., 1993; MacFarling Meure et al., 2006). The rapid rise of $\mathrm{CH}_{4}$ levels paused in the 1990s (Dlugokencky et al., 2003) and resumed strong growth of $\sim 8$ ppb yr $^{-1}$ again starting in 2007 (Rigby et al., 2008; Dlugokencky et al., 2009).

The factors responsible for the observed changes of $\mathrm{CH}_{4}$ concentration on historic (century to millennium) time scales as well as recent decades remain unclear in relation to $\mathrm{CH}_{4}$ emissions from natural and anthropogenic activities, climate change, and tropospheric oxidant changes. The stable carbon isotopic ratio $\left(\delta^{13} \mathrm{C}\right)$ of $\mathrm{CH}_{4}$ is useful for separating different $\mathrm{CH}_{4}$ sources, since individual sources have characteristic $\delta^{13} \mathrm{C}$ signatures (e.g. Quay et al., 1999). Ferretti et al. (2005) reported the significant $\delta^{13} \mathrm{C}$ depletion during the last millennium (circa 1000-1700 AD) and ascribed it to changes in biomass burning emissions probably influenced by both human activities and natural climate change. Houweling et al. (2008) suggested that the $\delta^{13} \mathrm{C}$ variation could alternatively be explained by increasing anthropogenic $\mathrm{CH}_{4}$ emissions over the past millennium, in combination with a shift from non-fossil to fossil sources during the industrial period. Analysing a Greenland ice core for $\delta^{13} \mathrm{C}$ and applying a twobox model, Sapart et al. (2012) attributed centennial-scale variations in $\delta^{13} \mathrm{C}$ between $100 \mathrm{BC}$ and $1600 \mathrm{AD}$ to changes in pyrogenic and biogenic sources driven by both natural climate variability and changes in human population and land use. It has been also suggested that changes in $\mathrm{CH}_{4}$ emission from natural wetlands were the dominant process, in the absence of anthropogenic sources, for $\mathrm{CH}_{4}$ variations during the Last Glacial Maximum (18 000 year before present, BP) to preindustrial Holocene (9000-200 year BP) (e.g. Chappellaz et al., 1993). All of these studies, with competing theories, are focused on the preindustrial era or before. They did not address the last century, which is a more complex situation due to the combination of natural and anthropogenic sources of $\mathrm{CH}_{4}$, and is the focus of this study.

The period between 1900 and the 1970s has no precise direct observations of $\mathrm{CH}_{4}$ concentration and $\delta^{13} \mathrm{C}$. Ice core studies have succeeded in reconstructing the $\mathrm{CH}_{4}$ concentration and $\delta^{13} \mathrm{C}$ history until the mid-20th century, and using firn air, the measurement record can be extended from the re- cent decades back to the mid-20th century (Etheridge et al., 1998; Ferretti et al., 2005; Francey et al., 1999; MacFarling Meure et al., 2006; Sapart et al., 2013). Both the ice core and firn air measurements can have relatively coarse time resolution (air age spread $(1 \sigma) \sim 5$ years or longer, Etheridge et al., 1998; Trudinger et al., 2002) and are mainly limited to polar regions, except for a recent ice core measurement from the Himalayan glacier which, however, has potential contaminations for $\mathrm{CH}_{4}$ in the air bubbles (Hou et al., 2013). Direct measurements of concentration at high precision were initiated in the late 1970s (e.g. Rasmussen and Khalil, 1984), and the measurement networks have grown to more than 100 sites worldwide (e.g. Cunnold et al., 2002; Dlugokencky et al., 2011). Here we use combined emissions from bottom-up inventories, emissions from wetlands and rice paddies simulated by a terrestrial biogeochemical model, and a 3-dimensional chemistry-transport model to simulate atmospheric $\mathrm{CH}_{4}$ for the past 100 years (1910-2010). With limited observations, attempts are made to estimate the optimized global total $\mathrm{CH}_{4}$ emissions by using mass balance calculations and to infer the possible variations in biomass burning emissions by introducing an additional constraint based on $\delta^{13} \mathrm{C}$. The biomass burning estimates are particularly useful for developing Representative Concentration Pathways (RCPs) for climate modelling with policy implications, e.g. the Intergovernmental Panel on Climate Change (IPCC) (Myhre et al., 2013; Lamarque et al., 2010). Section 2 describes the materials and methods, followed by results and discussion in Sect. 3, and finally, conclusions are given in Sect. 4.

\section{Materials and methods}

\subsection{Model description}

The Center for Climate System Research/National Institute for Environmental Studies/Frontier Research Center for Global Change (CCSR/NIES/FRCGC) Atmospheric General Circulation Model (AGCM)-based Chemistry Transport Model (i.e. JAMSTEC's ACTM) is used for simulating $\mathrm{CH}_{4}$ in the atmosphere (Patra et al., 2009). The model resolutions are T42 spectral truncations $\left(\sim 2.8^{\circ} \times 2.8^{\circ}\right)$ in horizontal and 67 sigma-pressure vertical layers (surface to $\sim 90 \mathrm{~km}$ ). In the control case, the ACTM meteorology is driven by interannually varying (IAV) sea-surface temperature (SST) and sea ice at monthly mean time intervals, based on the gridded analysis by the Hadley Centre (Rayner et al., 2003). The basic physical and dynamical features of the AGCM have been described in Hasumi et al. (2004). Advective transport of moisture and tracers is obtained from a 4th order flux-form advection scheme using a monotonic piecewise parabolic method (PPM) (Colella and Woodward, 1984) and a flux-form semiLagrangian scheme (Lin and Rood, 1996). Subgridscale vertical fluxes of heat, moisture and tracers are approximated us- 
ing a non-local closure scheme in conjugation with the level 2 scheme of Mellor and Yamada (1974). The cumulus parameterization scheme is based on Arakawa and Schubert (1974). The updraft and downdraft of tracers by cumulus convection are calculated by using the cloud mass flux estimated in the cumulus parameterization scheme. We have checked that the AGCM simulated zonal-mean horizontal winds and temperatures in the troposphere are within $\pm 5 \mathrm{~m} \mathrm{~s}^{-1}$ and $\pm 1 \mathrm{~K}$, respectively, when compared with ACTM simulations nudged to the Japan Meteorological Agency (JMA) 25 year reanalysis (JRA-25) (Onogi et al., 2007). These differences in meteorology do not appreciably affect our long-term simulation results, because only about $5 \mathrm{Tg} \mathrm{CH}_{4} \mathrm{yr}^{-1}(\sim 1 \%)$ higher loss is simulated in the ACTM driven only by SST compared to when the ACTM is nudged to JRA-25. The ACTM also realistically represents interhemispheric transport, stratospheretroposphere exchange, and SST driven climate variations such as the El Niño Southern Oscillation. Annual mean concentrations are used in this analysis, although the model integration time step is about $20 \mathrm{~min}$.

\section{$2.2 \mathrm{CH}_{4}$ emissions}

We constructed global total $\mathrm{CH}_{4}$ emissions by combining: (1) the interannually varying annual mean anthropogenic emissions from the Emission Database for Global Atmospheric Research (EDGAR) - Hundred Year Database for Integrated Environmental Assessments (HYDE; version 1.4) (van Aardenne et al., 2001) and EDGAR 3.2 (Olivier and Berdowski, 2001), (2) interannually and seasonally varying emissions from rice paddies and wetland simulated by the Vegetation Integrative Simulator for Trace Gases (VISIT) terrestrial ecosystem model (Ito and Inatomi, 2012), and (3) natural emissions, such as those from biomass burning (including biofuels), termites based on the GISS inventory (Fung et al., 1991); emissions due to oceanic exchange near the coastal region (Lambert and Schmidt, 1993); and mud volcano emissions (Etiope and Milkov, 2004) as the major emission components (Fig. 1a). We apply scaling factors for emissions due to termites, oceanic exchange, mud volcano, biomass burning, rice paddies and wetlands, with values of $0.77,0.40,1.00,0.4,0.95$, and 0.85 , respectively (please refer to the Supplement, Table S1, for annual total emissions). Scaling factors are chosen to simulate the $\mathrm{CH}_{4}$ growth rate approximately for the first decade 1901-1910, and are in close agreement with $\mathrm{Pa}-$ tra et al. (2011) for the period 1990-2008. For 1970-2000, interannually varying anthropogenic $\mathrm{CH}_{4}$ emissions from EDGAR 3.2 and EDGAR 3.2FT data are used and the data have been extended for 1901-1970 following the sector-wise trends recommended in EDGAR HYDE. For 2001-2010, the EDGAR 3.2FT emissions map for 2000 is used. EDGAR 3.2 and EDGAR 3.2FT emissions for biomass burning and rice sectors (SAV, DEF, AGR, AGL sectors) are excluded from the initial $\mathrm{CH}_{4}$ emissions $\left(E_{\mathrm{ini}}\right)$, since they are given from
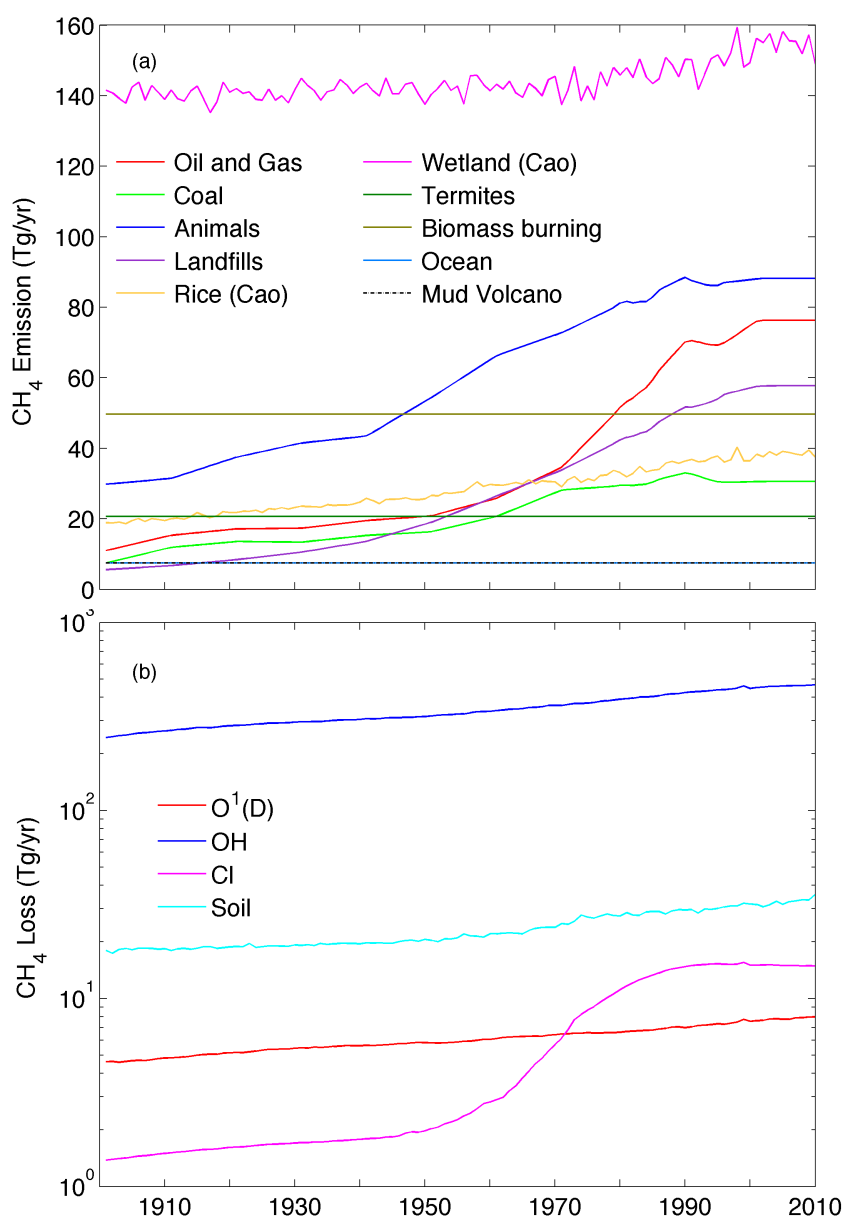

Figure 1. (a) Time series of $\mathrm{CH}_{4}$ emission inventory estimates from different categories during our simulation. (b) Chemical loss of $\mathrm{CH}_{4}$ calculated using ACTM simulation with initial emissions $\left(E_{\text {ini }}\right)$.

different data sets as described above. The combination of different categories (Table 1) and interpolation/extrapolation of the EDGAR data set are similar to that used by Patra et al. (2011).

All of the four main categories of anthropogenic emissions (oil and gas, coal, animals and landfills) have increased steadily in the last 110 years; according to the EDGAR inventories (HYDE, v3.2 and v3.2FT), oil and gas emissions increased from 12 to $78 \mathrm{Tg} \mathrm{yr}^{-1}$, coal from 9 to $33 \mathrm{Tg} \mathrm{yr}^{-1}$, animals from 30 to $89 \mathrm{Tg} \mathrm{yr}^{-1}$, and landfills from 6 to $59 \mathrm{Tg} \mathrm{yr}^{-1}$ for 1901-2010. The highest increases in these emissions took place during 1940-1990. Animal emissions were the dominant contributor to this rapid total increase for 1940-1960, while oil and gas controlled the increasing trend for the next 3 decades (1960-1990). There was a decrease in oil and gas emissions during the early 1990s from the former Soviet Union (Fig. 1a). We kept annual total biomass burning emissions constant over time $\left(49.7 \mathrm{Tg} \mathrm{yr}^{-1}\right.$; monthly varying GISS data set) because no consensus on the amplitude 
Table 1. Average source and sink strengths of $\mathrm{CH}_{4}$ for 1980-1989, isotopic ratios $\left(\delta^{13} \mathrm{C}_{E_{i}}\right)$ and fractionation factors $\left(\alpha_{\mathrm{i}}\right)$.

\begin{tabular}{|c|c|c|c|}
\hline Source/sink & Annual flux $\left(\mathrm{Tg} \mathrm{yr}^{-1}\right)$ & $\delta^{13} \mathrm{C}_{E_{i}}(\% o)$ & $\alpha_{\mathrm{i}}^{\mathrm{a}}$ \\
\hline \multicolumn{4}{|l|}{ Sources } \\
\hline Wetland & 146.8 & -59 & \\
\hline Rice & 34.2 & -63 & \\
\hline Animals & 83.5 & -62 & \\
\hline Termites & 20.7 & -57 & \\
\hline Biomass burning & 49.7 & -21.8 & \\
\hline Coal & 30.6 & -35 & \\
\hline Oil and gas & 59.2 & -40 & \\
\hline Landfills & 46.0 & -55 & \\
\hline Ocean & 7.4 & -59 & \\
\hline Mud volcanoes & 7.5 & -40 & \\
\hline$\Delta E^{\mathrm{b}}$ & 60.0 & -21.8 and -60.0 & \\
\hline Total source & 545.6 & & \\
\hline \multicolumn{4}{|l|}{ Sinks } \\
\hline $\mathrm{OH}$ & -451.5 & & 0.995350 \\
\hline $\mathrm{O}\left({ }^{1} \mathrm{D}\right)$ & -7.5 & & 0.994940 \\
\hline $\mathrm{Cl}$ & -14.5 & & 0.992532 \\
\hline Soil & -28.6 & & 0.978000 \\
\hline Total sinks & -502.1 & & \\
\hline
\end{tabular}

and trends has been achieved in the literature (see Sect. 3.4). The VISIT model simulated $\mathrm{CH}_{4}$ emissions from rice paddies and wetlands using a scheme by Cao et al. (1998). In the VISIT model, $\mathrm{CH}_{4}$ emission from wetlands is dependent on substrate availability, water table depth and temperature. The substrate availability was estimated from the decomposition rate of soil organic matter, assuming a certain part of carbon was used for methanogenesis. Water table depth was prescribed on the basis of inundation fraction, which varies seasonally. Aerobic soil fraction (i.e. above water table depth) is a sink of methane due to microbial oxidation, while anaerobic fraction (i.e. below water table depth) is a source of methane. Temperature (input data) explicitly affects methane production rate and implicitly affects gas diffusivity. The simulated total emissions from rice paddies increased from 18 to $37 \mathrm{Tg} \mathrm{yr}^{-1}$ and that from wetlands varied from 141 to $159 \mathrm{Tg} \mathrm{yr}^{-1}$ for the period 1901-2010. The trends in emissions from rice paddies are mainly due to the increase in rice cropping, and that for the wetlands are due to warming of the Earth's surface and inundation levels due to rainfall variations (Ito and Inatomi, 2012; Patra et al., 2013). The fraction of paddy field was derived from the cropland fraction in land use data (Hurtt et al., 2006).

\section{$2.3 \mathrm{CH}_{4}$ loss processes}

The primary loss process for atmospheric $\mathrm{CH}_{4}(\sim 90 \%)$ is oxidation by hydroxyl radicals $(\mathrm{OH})$, mostly in the troposphere. The remaining $\sim 10 \%$ of the sinks include consump- tion by methanotrophic bacteria in soils, and reactions with chlorine radicals $(\mathrm{Cl})$ and electronically excited atomic oxygen $\left(\mathrm{O}\left({ }^{1} \mathrm{D}\right)\right)$ in the stratosphere. The following chemical removal reactions for $\mathrm{CH}_{4}$ are prescribed in the ACTM forward simulations.

$$
\begin{aligned}
& \mathrm{CH}_{4}+\mathrm{OH} \stackrel{k_{\mathrm{OH}}}{\longrightarrow} \mathrm{CH}_{3}+\mathrm{H}_{2} \mathrm{O} \\
& {\left[k_{\mathrm{OH}}=2.45 \times 10^{-12} \exp (-1775 / T)\right]} \\
& \mathrm{CH}_{4}+\mathrm{O}^{1} \mathrm{D} \stackrel{k_{\mathrm{O}^{1} \mathrm{D}}}{\longrightarrow} \text { Products } \\
& {\left[k_{\mathrm{O}^{1} \mathrm{D}}=1.5 \times 10^{-10}\right]} \\
& \mathrm{CH}_{4}+\mathrm{Cl} \stackrel{k_{\mathrm{Cl}}}{\longrightarrow} \mathrm{CH}_{3}+\mathrm{HCl} \\
& {\left[k_{\mathrm{Cl}}=7.3 \times 10^{-12} \exp (-1280 / T)\right] .}
\end{aligned}
$$

The temperature $(T)$-dependent reaction rates $(k$; units: $\mathrm{cm}^{3}$ molecule $\mathrm{s}^{-1} \mathrm{~s}^{-1}$ ) are taken from Sander et al. (2006). The climatological monthly mean tropospheric $\mathrm{OH}$ concentrations are taken from Spivakovsky et al. (2000), and stratospheric $\mathrm{OH}$ and $\mathrm{Cl}$ concentrations are obtained from a stratospheric chemistry simulation by the CCSR/NIES AGCM (Takigawa et al., 1999). Concentration of $\mathrm{O}\left({ }^{1} \mathrm{D}\right)$ is calculated online in ACTM using climatological ozone distribution. Trends in $\mathrm{Cl}$ concentration over the period of our simulation are introduced using the estimated changes in effective equivalent tropospheric $\mathrm{Cl}$ for the period 1992-2012 (Montzka et al., 1999; updates on the NOAA/ESRL website) and by simple extrapolation to 1901 following the annual fluorocarbon production report of the Alternative Fluorocarbons Environmental Acceptability Study (AFEAS) (www. afeas.org). This method ignores the changes in $\mathrm{Cl}$ vertical distribution due to the differences in $\mathrm{Cl}$ production rate from different species, which is altitude dependent. A delay of about 5 years between emissions of the halocarbons at Earth's surface and $\mathrm{Cl}$ release in the stratosphere is used based on average "age" of stratospheric air in ACTM. No trends in $\mathrm{OH}$ are considered in this study because of the lack of consensus between models, e.g. 6 out of 14 models show increases in $\mathrm{OH}$ concentrations in the period of 1850 1980, even though the models used a consistent set of anthropogenic emissions since the preindustrial era (Naik et al., 2013).

The time series of $\mathrm{CH}_{4}$ chemical loss as calculated with ACTM simulation with $E_{\text {ini }}$ for 1901-2010 is shown in Fig. 1b. Loss due to $\mathrm{OH}$ is the dominant contributor (244$\left.466 \mathrm{Tg} \mathrm{yr}^{-1}\right)$, followed by soil $\left(18-36 \mathrm{Tg} \mathrm{yr}^{-1}\right.$ as simulated by the VISIT model), $\mathrm{O}\left({ }^{1} \mathrm{D}\right)\left(4.6-8 \mathrm{Tg} \mathrm{yr}^{-1}\right)$, and $\mathrm{Cl}(1.4$ 15.6 $\mathrm{Tg} \mathrm{yr}^{-1}$ ) over 1901-2010. Consideration of trends in $\mathrm{Cl}$ concentration in the ACTM results in a dramatic increase in $\mathrm{CH}_{4}$ loss by $\mathrm{Cl}$ since the 1950s (Fig. 1b). We show later that the trends in stratospheric feedback of ${ }^{13} \mathrm{C}$-enriched $\mathrm{CH}_{4}$ cause a large imbalance in the tropospheric budget of the emission categories. 


\section{4 $\mathrm{CH}_{4}$ observations: ice core/firn air data and direct measurements}

The observed $\mathrm{CH}_{4}$ concentrations in the Arctic and Antarctic regions were used for evaluating the ACTM simulations for two different emission scenarios. Two different types of data were used in the present study.

\subsubsection{Ice core/firn air measurements of $\mathrm{CH}_{4}$ concentration}

We used the Law Dome ice core records (DSS, DE08 and DE08-2) (Etheridge et al., 1998; Ferretti et al., 2005; MacFarling Meure et al., 2006) (1894-1980), and the firn records from DE08-2 (Etheridge et al., 1998) and DSSW20K (MacFarling Meure et al., 2006 and references therein) (19441995). The NEEM firn data (1945-2005) are based on the measurements given in Buizert et al. (2012) with effective ages assigned using an iterative dating method (Trudinger et al., 2002) using the CSIRO firn model (Trudinger et al., 2013) tuned for NEEM with nine tracers $\left(\mathrm{CH}_{4}\right.$ was not used). The NGRIP firn air data (1951-2001) are obtained from Tohoku University (Umezawa et al., unpublished data). Age to each sampling depth for NGRIP firn data is assigned following the method employed for $\mathrm{N}_{2} \mathrm{O}$ (Ishijima et al., 2007). This method is based on an "effective age" concept by Trudinger et al. (2002), and uses a firn model by Sugawara et al. (2003). A scaling factor to convert the effective diffusivity of $\mathrm{CO}_{2}$ to that of $\mathrm{CH}_{4}$ is used as 1.291.

\subsubsection{Direct atmospheric measurements from sampling networks or air archive}

Direct measurements of atmospheric $\mathrm{CH}_{4}$ from two representative sites are used: (1) the Southern Hemisphere high latitude (Cape Grim; CGO; $40.7^{\circ} \mathrm{S}, 144.7^{\circ} \mathrm{E}$ ) and (2) the Northern Hemisphere high latitude (Summit; SUM; $72.6^{\circ} \mathrm{N}$, $38.5^{\circ} \mathrm{W}$ ). We used station data whenever available from the NOAA Earth System Research Laboratory (NOAA/ESRL) (Dlugokencky et al., 1994); and from the Global Atmospheric Gases Experiment (GAGE) and the Advanced Global Atmospheric Gases Experiment (AGAGE) program (Prinn et al., 2000; Cunnold et al., 2002). Annual mean values are calculated from flask-based or continuous measurement data for these sites available on the World Data Centre for Greenhouse Gases (WDCGG) website (http://ds.data.jma. go.jp/gmd/wdcgg). The archived air samples (1978-1995) from CGO are taken from Etheridge et al. (1998).

\subsubsection{Processing of observation data and sampling of model}

We applied scaling factors following Dlugokencky et al. (2005), for harmonizing all $\mathrm{CH}_{4}$ data onto the Tohoku University (TU) scale (Aoki et al., 1992; Umezawa et al., 2014). The NOAA04 scale is about 2 ppb lower that the
TU scale at $\mathrm{CH}_{4}$ concentration of $1700 \mathrm{ppb}$. It is noted that the ice core and firn air measurements have time resolution of $\sim 5$ years or more (air age spread $(1 \sigma)$, Etheridge et al., 1998; Trudinger et al., 2002), while the direct measurements are available at either weekly or sub-hourly time intervals. The measurement accuracy for air samples is $5 \mathrm{ppb}$ or better (Etheridge et al., 1998; Umezawa et al., 2014; Dlugokencky et al., 1994; Cunnold et al., 2002). To prepare the time series of observed $\mathrm{CH}_{4}$ concentration at uniform annual intervals, first the annual average of all observations was estimated and then the annual average data at uneven time intervals (due to data gaps) were interpolated using spline (order 4) fitting. The spline fitting is adopted using the SPLINEFIT program by Jonas Lundgren (www.mathworks.com/matlabcentral/ fileexchange/13812-splinefit). The smoothing effect is controlled by the judicious selection of breaks or knots at different years. The knots are needed for finding optimal fit through data at irregular time intervals and changing concentration growth rate.

The annual mean concentrations of ACTM simulations are sampled at Cape Grim for the Antarctic region and Summit for the Arctic region. The direct measurements at these two sites for the decade of 2000s show good agreements (modeldata mismatch less than $3 \mathrm{ppb}$, discussed later in detail) with the ACTM simulation using optimized emissions, and the Cape Grim data are also homogenized with those from Law Dome measurements (Etheridge et al., 1998).

\subsection{Calculation of optimized $\mathrm{CH}_{4}$ emission: mass balance}

The global mass balance equation for total emissions $(E)$, loss $(L)$ and burden $(B)$ of $\mathrm{CH}_{4}$ in the atmosphere is given by:

$\frac{\mathrm{d} B}{\mathrm{~d} t}=E-L$.

A conversion factor $H$ can be calculated from the ratio of modelled $B$ and an average $\mathrm{CH}_{4}$ concentration at the lowermost model level $\left(\left[\mathrm{CH}_{4}\right]\right)$ as follows:

$B=H \times\left[\mathrm{CH}_{4}\right]$.

This gives the value of $2.87 \pm 0.003$ (average \pm interannual variation) $\mathrm{Tg} \mathrm{CH}_{4} \mathrm{ppb}^{-1}$ for the conversion factor $H$ for the period 1910-2010. This value of $H$ is about $4 \%$ higher than common value of 2.77 calculated by Fung et al. (1991). This is mainly because in the present calculation we have used smaller than global mean $\mathrm{CH}_{4}$ concentration from Antarctica. $L$ is calculated by summing up loss at all ACTM grids. Because our knowledge for developing accurate initial emissions $\left(E_{\mathrm{ini}}\right)$ is incomplete, the simulated $\left[\mathrm{CH}_{4}\right]$ time series is likely to deviate from the observation. The "correction" term $\Delta E$ to initial emission time series is calculated by applying Eq. (1) on the difference $\left(\Delta\left[\mathrm{CH}_{4}\right]\right)$ between observed and 
Table 2. Average bias and $1 \mathrm{SD}$ (in ppb) of model-observed $\mathrm{CH}_{4}$ concentration for each decade over the Antarctic region. The averages of $E_{\text {ini }}, E_{\text {opt }}$ and $B_{\text {opt }}$ for each decade are also shown. The annual mean values for all years are given in Table S2.

\begin{tabular}{|c|c|c|c|c|c|}
\hline \multirow[t]{2}{*}{ Decade } & \multicolumn{2}{|c|}{ Model-observation $\mathrm{CH}_{4}$ concentration (ppb) } & \multirow{2}{*}{$\begin{array}{c}E_{\text {ini }} \\
\left(\operatorname{Tg}^{-1}\right)\end{array}$} & \multirow{2}{*}{$\begin{array}{c}E_{\mathrm{opt}} \\
\left(\mathrm{Tg}_{\mathrm{yr}}^{-1}\right)\end{array}$} & \multirow{2}{*}{$\begin{array}{l}B_{\mathrm{Opt}} \\
(\mathrm{Tg})\end{array}$} \\
\hline & with $E_{\text {ini }}$ & with $E_{\text {opt }}$ & & & \\
\hline 1910-1919 & $40.94 \pm 3.29$ & $-3.31 \pm 0.51$ & 315.0 & 300.1 & 2686.4 \\
\hline 1920-1929 & $37.33 \pm 5.30$ & $-2.07 \pm 0.37$ & 326.4 & 319.9 & 2846.7 \\
\hline 1930-1939 & $21.21 \pm 3.25$ & $-0.44 \pm 0.67$ & 337.0 & 334.1 & 3002.7 \\
\hline 1940-1949 & $13.92 \pm 1.85$ & $0.05 \pm 0.39$ & 351.2 & 349.2 & 3132.0 \\
\hline $1950-1959$ & $0.13 \pm 6.84$ & $-0.61 \pm 0.44$ & 375.7 & 381.9 & 3331.7 \\
\hline 1960-1969 & $-38.96 \pm 16.31$ & $0.11 \pm 1.26$ & 407.2 & 434.4 & 3675.5 \\
\hline $1970-1979$ & $-101.88 \pm 20.66$ & $-1.04 \pm 0.75$ & 442.4 & 491.6 & 4109.6 \\
\hline 1980-1989 & $-160.65 \pm 14.15$ & $0.15 \pm 1.59$ & 485.6 & 545.6 & 4572.7 \\
\hline 1990-1999 & $-161.76 \pm 8.37$ & $2.54 \pm 2.12$ & 515.0 & 557.8 & 4878.8 \\
\hline $2000-2009$ & $-122.40 \pm 15.34$ & $2.67 \pm 3.25$ & 531.0 & 555.0 & 4973.2 \\
\hline
\end{tabular}

simulated $\left[\mathrm{CH}_{4}\right]$ :

$H \frac{\mathrm{d}\left(\Delta\left[\mathrm{CH}_{4}\right]\right)}{\mathrm{d} t}+\Delta L=\Delta E$

where $\Delta L$ is the difference in loss terms which is calculated using $\Delta\left[\mathrm{CH}_{4}\right]$ and the ratio $L /\left[\mathrm{CH}_{4}\right]$ as a conversion factor $(0.2907 \pm 0.0055)$ from model simulation for individual years. The optimized emissions $\left(E_{\mathrm{opt}}\right)$ are given by

$E_{\mathrm{opt}}=E_{\text {ini }}+\Delta E$.

The calculation of global total $E_{\text {opt }}$ is performed for each year. Emissions at all latitude-longitude grids are multiplied by a constant scaling factor $\left(\frac{E_{\text {opt }}}{E_{\text {ini }}}\right)$ to prepare revised emission for running ACTM.

\subsection{Isotope analysis}

The contribution of different emission categories $\left(E_{\mathrm{ini}_{i}}\right)$ to the bottom-up emissions as used in this study is prescribed (Fig. 1a and Table 1). However, the relative contribution of different emission categories to the emission correction $\Delta E$ is unknown. We thus introduce an additional constraint based on $\delta^{13} \mathrm{C}$ for distributing $\Delta E$ between two hypothetical source categories with lighter $\left({ }^{13} \mathrm{C}\right.$-depleted $)$ and heavier $\left({ }^{13} \mathrm{C}\right.$-enriched) isotopic signatures.

The isotopic ratio of ${ }^{13} \mathrm{C}$ to ${ }^{12} \mathrm{C}$ in $\mathrm{CH}_{4}\left(\delta^{13} \mathrm{C}\right)$ is defined as:

$\delta^{13} \mathrm{C}=\left(\frac{R_{\text {sample }}}{R_{\text {std }}}-1\right) \times 1000$

$R={ }^{13} \mathrm{C} /{ }^{12} \mathrm{C}$,

where $R_{\text {sample }}$ is the isotopic molar ratio in the methane sample, and $R_{\text {std }}$ is the corresponding ratio in the international isotope standard (Vienna Pee Dee Belemnite (VPDB)) with an accepted value of 0.0112372 (Craig, 1957). $\delta^{13} \mathrm{C}$ is expressed in "per mil" (\%o) notation.
We use a one-box model (e.g. Lassey et al., 2000) to estimate the isotopic signature for global emission $E\left(\delta^{13} \mathrm{C}_{E}\right)$ using (1) global atmospheric burden $(B)$ and loss $(L)$ taken from the ACTM simulation and (2) observed atmospheric isotope ratio $\delta^{13} \mathrm{C}_{\text {atmos }}$. We used $\delta^{13} \mathrm{C}_{\mathrm{atmos}}$ observations from the Law Dome ice core (1885-1976)/firn (1944-1998) records (Ferretti et al., 2005); from air archive samples (1978-1994) (Francey et al., 1999); and NOAA-ESRL network direct observations (1998-2010) at CGO (Miller et al., 2002; White and Vaughn, 2011). Schmitt et al. (2013) reported a possible interfering effect by $\mathrm{Kr}$ on $\delta^{13} \mathrm{C}$ measurements using continuous-flow isotope ratio mass spectrometry systems. We assume that possible bias caused by the $\mathrm{Kr}$ interference is not significant in deducing the observed $\delta^{13} \mathrm{C}$ trends over the past century.

The $\delta^{13} \mathrm{C}$ signature for the global source $\delta^{13} \mathrm{C}_{E}$ can be calculated in two different ways: top-down and bottom-up methods. First, the top-down estimation is based on using the observed atmospheric isotope ratio $\delta^{13} \mathrm{C}_{\mathrm{atmos}}$ and mass balance Eq. (1) as follows:

$$
\begin{aligned}
& { }^{13} E=\frac{\mathrm{d}}{\mathrm{d} t}\left({ }^{13} B\right)+\sum^{13} L_{i} \\
& { }^{13} B=\left(\delta^{13} \mathrm{C}_{\mathrm{atmos}} \times 0.001+1\right) \times R_{\mathrm{std}} \times B \\
& { }^{13} L_{i}=L_{i} \times \alpha_{\mathrm{i}} \times R_{\mathrm{atmos}} \\
& \delta^{13} \mathrm{C}_{E}=\left[\frac{{ }^{13} E}{E \times R_{\text {std }}}-1\right] \times 1000,
\end{aligned}
$$

where $L_{i}$ are the loss processes due to reactions with $\mathrm{OH}$, $\mathrm{O}\left({ }^{1} \mathrm{D}\right), \mathrm{Cl}$ and soil oxidation, $\alpha_{\mathrm{i}}={ }^{13} k_{\mathrm{i}} /{ }^{12} k_{\mathrm{i}}$ is the isotopic fractionation factors for different loss processes, $k$ is the rate coefficient of chemical reactions. The choice of $\alpha_{\mathrm{i}}$ used in this work and their uncertainties are addressed later in this section. Superscript 13 refers to the carbon isotopologue ${ }^{13} \mathrm{C}$ in $\mathrm{CH}_{4}$. In the one-box model, we assume that burden $\left.{ }^{[12} \mathrm{CH}_{4}\right]$ is identical to $\left[\mathrm{CH}_{4}\right]$, which however is the sum of 
$\left[{ }^{12} \mathrm{CH}_{4}\right],\left[{ }^{13} \mathrm{CH}_{4}\right]$ and other minor isotopologues. We confirmed that this assumption has a negligible effect on our results. Our results are consistent with the calculation of $\delta^{13} \mathrm{C}_{E}$ under non-steady-state conditions (Lassey et al., 2000).

Secondly, $\delta^{13} \mathrm{C}_{E}$ can be calculated by considering the relative fractions of individual emission categories $\left(E_{i}\right)$ as follows (bottom-up estimation):

$\delta^{13} \mathrm{C}_{E}=\sum\left(\delta^{13} \mathrm{C}_{E_{i}} \times E_{i}\right) / E$,

where $E=\sum E_{i}$ and $\delta^{13} C_{E_{i}}$ is the isotopic signature for emission category $E_{i}$. For the optimized case, $E=$ $E_{\mathrm{opt}}=\sum E_{\mathrm{ini}_{i}}+\Delta E$, and $L_{i}=L_{\mathrm{opt}_{i}}$ and $B=B_{\mathrm{opt}}$ from the ACTM simulation should represent the observed condition. Using Eqs. (5)-(10), we calculate the isotope signature for $E_{\text {opt }}\left(\delta^{13} C_{E_{\text {opt }}}\right)$. Again $\delta^{13} C_{E_{\mathrm{opt}}}$ can be estimated using Eq. (11) with $E_{\mathrm{opt}}=\sum E_{\mathrm{ini}_{i}}+\Delta E$. Here we assume that $\Delta E$ is distributed between two hypothetical emissions $\Delta E_{1}$ and $\Delta E_{\mathrm{h}}$ with lighter $\left(\delta^{13} \mathrm{C}_{\Delta E_{1}}\right)$ and heavier $\left(\delta^{13} \mathrm{C}_{\Delta E_{\mathrm{h}}}\right)$ isotopic signatures, respectively. The $\delta^{13} \mathrm{C}_{E_{i}}$ are taken from Monteil et al. (2011) and references therein (Table 1). Using Eq. (11), we obtain,

$$
\begin{aligned}
& \delta^{13} \mathrm{C}_{E_{\mathrm{opt}}}= \\
& \frac{\sum \delta_{E_{\mathrm{ini}_{i}}}^{13} \times E_{\mathrm{ini}_{i}}+\delta^{13} \mathrm{C}_{\Delta E_{1}} \times \Delta E_{1}+\delta^{13} \mathrm{C}_{\Delta E_{\mathrm{h}}} \times \Delta E_{\mathrm{h}}}{E_{\mathrm{opt}}} .
\end{aligned}
$$

And we have an additional constraint on $\Delta E_{1}$ and $\Delta E_{\mathrm{h}}$ as follows:

$\Delta E=\Delta E_{1}+\Delta E_{\mathrm{h}}$.

The value of $\delta^{13} \mathrm{C}_{E_{\text {opt }}}$ as calculated using Eq. (10) is substituted into Eq. (12). There is, however, no unique solution for Eqs. (12) and (13) as they contain four unknown variables $\left(\Delta E_{\mathrm{h}}, \Delta E_{1}, \delta^{13} \mathrm{C}_{\Delta E_{\mathrm{h}}}\right.$ and $\left.\delta^{13} \mathrm{C}_{\Delta E_{1}}\right)$. In order to remove the underdetermination, we assume that $\delta^{13} \mathrm{C}_{\Delta E_{\mathrm{h}}}$ and $\delta^{13} \mathrm{C}_{\Delta E_{1}}$ represent emissions from biomass burning $\left(\delta^{13} \mathrm{C}\right.$ is $-21.8 \%$ o from Monteil et al., 2011) and residual biogenic sources (e.g. wetland, rice, animals, etc., mean $\delta^{13} \mathrm{C}$ near to $-60 \%$ from Sapart et al., 2012), respectively. Equation (12) can now be modified to:

$$
\begin{aligned}
& \Delta E_{1}= \\
& \frac{\delta^{13} \mathrm{C}_{E_{\mathrm{opt}}} \times E_{\mathrm{opt}}-\sum \delta_{E_{\mathrm{ini}_{i}}}^{13} \times E_{\mathrm{int}_{i}}-\delta^{13} \mathrm{C}_{\Delta E_{\mathrm{h}}} \times \Delta E}{\left(\delta^{13} \mathrm{C}_{\Delta E_{1}}-\delta^{13} \mathrm{C}_{\Delta E_{\mathrm{h}}}\right)}
\end{aligned}
$$

Using Eq. (14) we can estimate $\Delta E_{1}$ and then $\Delta E_{\mathrm{h}}$ is calculated using Eq. (13). Estimation of emissions due to biomass burning is our primary interest here because no direct statistics are available over the past century and it was assumed constant at $49.7 \mathrm{Tg} \mathrm{yr}^{-1}$ in $E_{\text {ini. }}$. It may be reiterated here that the anthropogenic emissions varied as per the EDGAR inventories, and wetland and rice emissions are taken from a terrestrial ecosystem model simulation.
Although $\mathrm{CH}_{4}$ losses due to reactions with $\mathrm{Cl}$ and $\mathrm{O}\left({ }^{1} \mathrm{D}\right)$, which mainly take place in the stratosphere, are small compared to the total loss, the strong isotopic fractionations $\left(\varepsilon_{\mathrm{i}}=\left(\alpha_{\mathrm{i}}-1\right) \times 1000 ; \varepsilon_{\mathrm{i}}\right.$ is also known as "kinetic isotope effect" (KIE)) in these reactions have a large impact on the isotopic budget (Lassey et al., 2007a; Wang et al., 2002). The isotopic fractionation factors $\left(\alpha_{\mathrm{i}}\right)$ for the $\mathrm{CH}_{4}+\mathrm{Cl}$ reaction $\left(\alpha_{\mathrm{Cl}}=0.935\right)$ is much smaller than that of the $\mathrm{CH}_{4}+\mathrm{OH}$ and $\mathrm{CH}_{4}+\mathrm{O}\left({ }^{1} \mathrm{D}\right)$ reactions, e.g. $\alpha_{\mathrm{OH}}=0.9961$ and $\alpha_{\mathrm{O}\left({ }^{1} \mathrm{D}\right)}=$ 0.9872 , respectively (Saueressig et al., 1995). Previous studies have shown that there exists a large vertical gradient in $\delta^{13} \mathrm{C}$ from the troposphere to the stratosphere due to the stronger fractionation effects in $\mathrm{CH}_{4}+\mathrm{O}\left({ }^{1} \mathrm{D}\right)$ and $\mathrm{CH}_{4}+\mathrm{Cl}$ reactions during passage through the stratosphere (Rice et al., 2003; Röckmann et al., 2011; Sugawara et al., 1997). Stratosphere air returning to the troposphere is enriched in ${ }^{13} \mathrm{CH}_{4}$, but the re-entry flux and consequent ${ }^{13} \mathrm{CH}_{4}$ enrichment in the troposphere are not well quantified (Lassey et al., 2007a). In a modelling study, Wang et al. (2002) estimated that the tropospheric ${ }^{13} \mathrm{CH}_{4}$ enrichment for 1992 due to stratospheric $\mathrm{Cl}$ without assuming steady state was $0.23 \%$ o $(0.18-0.54 \%$ o). If the $\alpha_{\mathrm{i}}$ for $\mathrm{Cl}$ and $\mathrm{O}\left({ }^{1} \mathrm{D}\right)$ loss processes as mentioned above (Saueressig et al., 1995) are used in the one-box model, because of the strong isotopic fractionations, the isotopic effect of stratospheric $\mathrm{CH}_{4}$ loss on the tropospheric $\delta^{13} \mathrm{C}$ budget will be overestimated. To avoid such overestimation, we assume that $\alpha_{\mathrm{i}}$ in the troposphere are mainly due to $\mathrm{OH}$ loss, and a smaller fractionation effect of the stratospheric loss on $\delta{ }^{13} \mathrm{C}$ at the surface. In fact, the magnitude of fractionation during $\mathrm{CH}_{4}$ loss, both in the troposphere and stratosphere, is uncertain since the published values of $\alpha_{\mathrm{i}}$ in the literature are significantly different. The values of $\alpha_{\mathrm{Cl}}$ range from about 0.935 (Saueressig et al., 1995) to 0.966-0.974 (Tanaka et al., 1996; Gupta et al., 1997), $\alpha_{\mathrm{O}^{1}(\mathrm{D})}$ from 0.9872 (Saueressig et al., 2001) to 0.999 (Davidson et al., 1987) and $\alpha_{\mathrm{OH}}$ from 0.9946 (Cantrell et al., 1990) to 0.9961 (Saueressig et al., 2001). In the present study, $\alpha_{\mathrm{OH}}$ is the mean of two published $\alpha_{\mathrm{OH}}$ values (Cantrell et al., 1990; Saueressig et al., 2001). We scaled $\alpha_{\mathrm{Cl}}$ so that the reaction with $\mathrm{Cl}$ has an impact of $+0.23 \%$ on surface $\delta^{13} \mathrm{C}$ in 1992 , to be consistent with Wang et al. (2002). $\alpha_{\mathrm{O}\left({ }^{1} \mathrm{D}\right)}$ is also adjusted by keeping the ratio $\left(\alpha_{\mathrm{Cl}}-\alpha_{\mathrm{OH}}\right) /\left(\alpha_{\mathrm{O}\left({ }^{1} \mathrm{D}\right)}-\alpha_{\mathrm{OH}}\right)$ and total loss by reactions with $\mathrm{Cl}$ and $\mathrm{O}\left({ }^{1} \mathrm{D}\right)$ unchanged. The weighted mean isotopic fractionation factor $(\overline{\bar{\alpha}})$ for all loss processes is 0.9943 and the global mean $\delta^{13} C_{E}$ value in 1990 is $-52.1 \%$, which are in agreement with other estimates, e.g. 0.9941 and $-52.3 \%$, respectively (e.g. Lassey et al., 2000). The values of $\alpha_{\mathrm{Cl}}$ and $\alpha_{\mathrm{O}^{1}(\mathrm{D})}$ used in this study are now much closer to that of $\alpha_{\mathrm{OH}}$ producing the smaller fractionation effect of stratospheric loss on the estimation of $\delta^{13} \mathrm{C}$ at the surface (Table 1). Due to the increase in atomic $\mathrm{Cl}$ in stratosphere, the effect of $\alpha_{\mathrm{Cl}}$ on surface $\delta^{13} \mathrm{C}$ is estimated to increase from +0.01 to $+0.38 \%$ o during the period 1910-2010. 


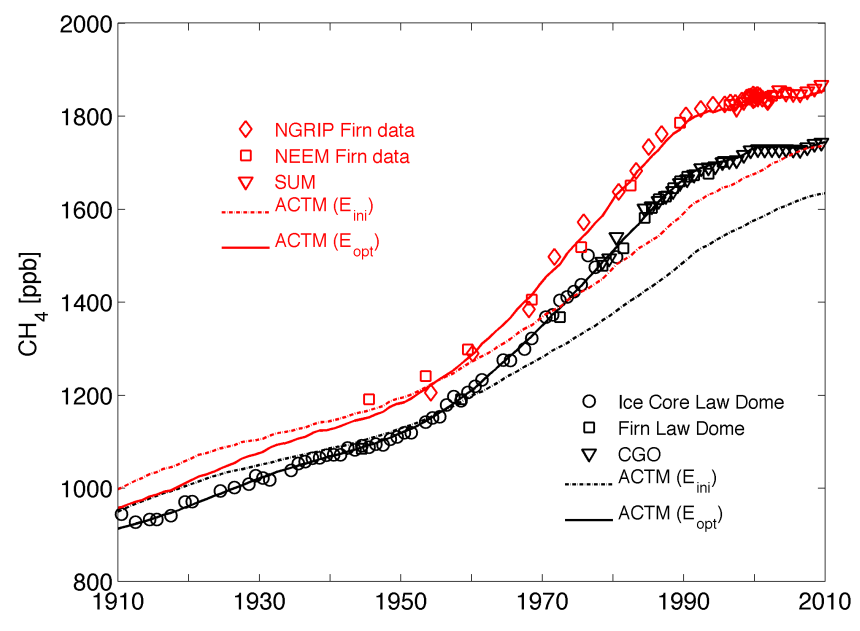

Figure 2. ACTM simulations of $\mathrm{CH}_{4}$ concentration compared with ice core, firn and direct measurements. ACTM simulated $\mathrm{CH}_{4}$ concentrations with $E_{\text {ini }}\left(E_{\mathrm{opt}}\right)$ for the Arctic and Antarctic regions are shown in magenta (blue) and purple (green), respectively. The red (black) symbols and text are for the Arctic (Antarctic) region. Annual average ice core data (Law Dome: DSS, DE08 and DE082), firn records (Law Dome (DE08-2 and DSSW20K); NGRIP firn data; and NEEM firn data) and direct observations (CGO: air archive, flask sampling and GAGE/AGAGE; SUM: flask sampling) are prepared and presented separately here. All the observation data are referenced to the Tohoku University (TU) $\mathrm{CH}_{4}$ scale (Aoki et al., 1992; Umezawa et al., 2014).

\section{Results and discussion}

\subsection{Model-observation comparisons of $\mathrm{CH}_{4}$ concentrations}

The model simulations are compared with the observed $\mathrm{CH}_{4}$ concentration time series constructed from ice core, firn air, air archives and ambient air measurements (Fig. 2). The first 9 years (1901-1909) of the simulation are used to spin-up the ACTM, to guarantee that the results are independent of the initial conditions. The initial ACTM simulation using $E_{\text {ini }}$ (Fig. 2) underestimates the growth rate by $0.6 \mathrm{ppbyr}^{-1}$ $\left(4.8 \mathrm{ppbyr}^{-1}\right)$ for the period of slow (rapid) growth during 1910-1950 (1950-1990), and it also fails to capture the slowdown of the observed $\mathrm{CH}_{4}$ growth rate during the 1990s. Apparently, the $E_{\text {ini }}$ is a better first-guess in the first half of the 20th century compared to the latter half, when the $\mathrm{CH}_{4}$ growth rate changed dramatically. The model-observation mismatches are attributed to incomplete knowledge of $E_{\text {ini }}$ as used in the ACTM simulations, assuming no significant uncertainties in chemistry and transport. Thus we have estimated optimized global total $\mathrm{CH}_{4}$ emissions using the mass balance calculation as described in Sect. 2.5.

A new ACTM simulation using optimized emissions ( $\left.E_{\text {opt }}\right)$ was performed and the modelled $\mathrm{CH}_{4}$ concentrations for the Arctic and Antarctic regions (blue and green, respectively) are shown in Fig. 2. Simulated and observed $\mathrm{CH}_{4}$ are in good agreement for the ACTM using $E_{\text {opt }}$ (see Table 2 for detailed statistics). Observations in the Antarctic region reveal that the growth rates are: moderate $\left(5.1 \mathrm{ppb} \mathrm{yr}^{-1}\right)$ during 1910-1950; fastest (13.6 $\mathrm{ppbyr}^{-1}$ ) during 1950-1990; moderate $\left(6.7 \mathrm{ppb} \mathrm{yr}^{-1}\right)$ during the $1990 \mathrm{~s}$; near-steady in the early 2000s; and moderate again $\left(5.7 \mathrm{ppb} \mathrm{yr}^{-1}\right)$ since 2007 . These are all simulated well by ACTM within the measurement uncertainties of 2-5 ppb. $\mathrm{CH}_{4}$ observations in the Arctic region only cover 1945-2010. The ACTM simulated growth rates for the Arctic region follow a similar trend as the Antarctic region: $5.6 \mathrm{ppb} \mathrm{yr}^{-1}$ during $1910-1950 ; 15.2 \mathrm{ppb} \mathrm{yr}^{-1}$ during $1950-1990 ; 5.2 \mathrm{ppb} \mathrm{yr}^{-1}$ during the 1990s; near-steady state during the early 2000s; and $5.8 \mathrm{ppbyr}^{-1}$ since 2007 . The inter-polar difference (IPD) of $\mathrm{CH}_{4}$ is, however, smaller in the model simulation (102.2 $\pm 17.9 \mathrm{ppb})$ compared to observations (117 $\pm 16.7 \mathrm{ppb})$ for the period 1949-2010. A detailed discussion on IPD is given in Sect. 3.3.

\subsection{Trends in methane lifetime}

As no consensus has been reached for the trends in global mean $\mathrm{OH}$ concentration simulated by state-of-the-art CTMs (e.g. John et al., 2012), we used monthly varying climatological $\mathrm{OH}$ concentrations for our ACTM simulations. This $\mathrm{OH}$ distribution, from Spivakovsky et al. (2000), also fits well with ACTM transport for simulating inter-hemispheric gradients in $\mathrm{CH}_{3} \mathrm{CCl}_{3}$ and $\mathrm{CH}_{4}$ for the period 1988-2010 (Patra et al., 2011, 2014). The $\mathrm{OH}$ field is scaled by 0.92 for simulating the decay rate of $\mathrm{CH}_{3} \mathrm{CCl}_{3}$ in Earth's atmosphere (Krol and Lelieveld, 2003). For $E_{\text {opt }}$ the total $\mathrm{CH}_{4}$ lifetime is given by $\tau_{\text {Total }}=\frac{B_{\mathrm{opt}}}{\left(E_{\mathrm{opt}}-\frac{\mathrm{d} B_{\mathrm{opt}}}{\mathrm{d} t}\right)}$. The trends in $\mathrm{CH}_{4}$ lifetime and tropospheric mean temperature anomaly are shown in Fig. 3. The average $\mathrm{CH}_{4}$ total lifetime during 1910-1919 and 20002009 are $9.4 \pm 0.09$ and $9.0 \pm 0.09$ years, respectively. The ACTM simulated air temperature anomaly is very similar to that of the observed temperature anomaly produced at GISS (Hansen et al., 2010). This illustrates that the long-term simulation of $\mathrm{CH}_{4}$ by ACTM, driven by analysed SST only, is close to that simulated by ACTM nudged to the reanalysis meteorology. To examine the factors causing change in the $\mathrm{CH}_{4}$ lifetime, we have calculated the temporal change of "apparent reaction rate" $k_{\mathrm{a}, i}=L_{i} / B$, where $i$ is the $\mathrm{CH}_{4}$ reaction with $\mathrm{OH}, \mathrm{O}\left({ }^{1} \mathrm{D}\right), \mathrm{Cl}$ or soil oxidation. Between the 1910 s and the 2000s, contributions of $\mathrm{Cl}, \mathrm{OH}, \mathrm{O}\left({ }^{1} \mathrm{D}\right)$ reactions and soil oxidation to $\mathrm{CH}_{4}$ lifetime change are $+61.7,+48.7,-1.6$ and $-8.8 \%$, respectively. Thus, the $\sim 4 \%$ shorter average $\mathrm{CH}_{4}$ total lifetime from the first to the last decades of the last 100 years (1910-2009) is mainly caused by the large increase in $\mathrm{Cl}$ concentration and the increase in the tropospheric air temperature. 


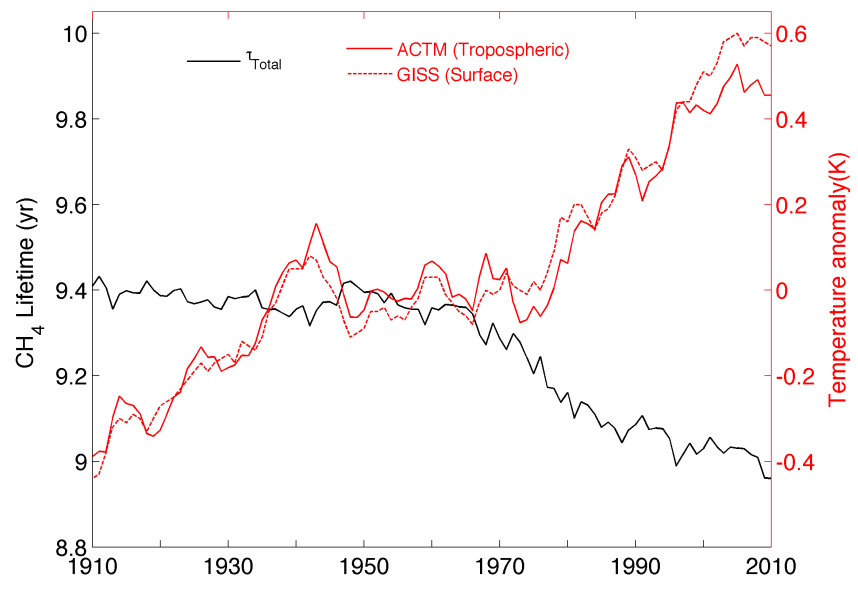

Figure 3. Five-year running means of $\mathrm{CH}_{4}$ total lifetime and global tropospheric temperature anomaly (with the base period 19511980) during 1910-2010.

\subsection{Estimation of global total $\mathrm{CH}_{4}$ emissions for improved concentration simulations}

Global total $\mathrm{CH}_{4}$ emissions are optimized by minimizing the model-observation mismatches of $\mathrm{CH}_{4}$ concentrations over the Antarctic region (combined measurements from Law Dome ice core/firn air and direct air sampling from Cape Grim). Figure 4 shows a comparison of both the initial and optimized emissions with TransCom- $\mathrm{CH}_{4}$ emissions ( $\mathrm{CH}_{4}$ EXTRA) for 1988-2010 (Patra et al., 2011). The increase rate of global total emissions is underestimated (overestimated) by $\sim 30 \%$ ( 380\%) during 1940-1989 (1990$2009)$ in the initial emission scenario. Optimized emissions $\left(E_{\text {opt }}\right)$ are in overall agreement with TransCom $\mathrm{CH}_{4}$ emissions for 1988-2010. This indicates robustness of the massbalance based optimization used in this study. For quantitative assessment of ACTM simulations with all the emissions scenarios $\left(E_{\text {ini }}\right.$ and $E_{\text {opt }}$ ), the model-observation $\mathrm{CH}_{4}$ concentration biases and SDs $(1 \sigma)$ (in ppb) of the biases over the Antarctic region, and averages of $E_{\mathrm{ini}}, E_{\mathrm{opt}}$ and $B_{\mathrm{opt}}$ for each decade are summarized in Table 2. Both the bias and $1 \sigma$ are reduced drastically when optimized global total emissions are used in ACTM (Table 2). It may be reiterated here that the global total emissions for mass balance is dependent on the $\mathrm{CH}_{4}$ loss rates as parameterized in ACTM (Eq. 1).

Figure 5 shows inter-polar differences (IPD) of $\mathrm{CH}_{4}$ concentration using the ACTM simulations with $E_{\text {ini }}$ and $E_{\text {opt }}$ over Arctic and Antarctic regions for 1910-2010. For the observations, we used a combination of data sets from Arctic (NGRIP firn air: 1953-2001, NEEM firn air: 1945-1996 and direct measurements at SUM since 1998) and Antarctic (Law Dome ice cores: 1901-1980, DE08-2 and DSSW20K firn air: 1978-1993, and direct measurements and archive tanks at CGO since 1978) regions. It is noted that no observation for 1910-1945 is available from the Arctic region, so the IPD

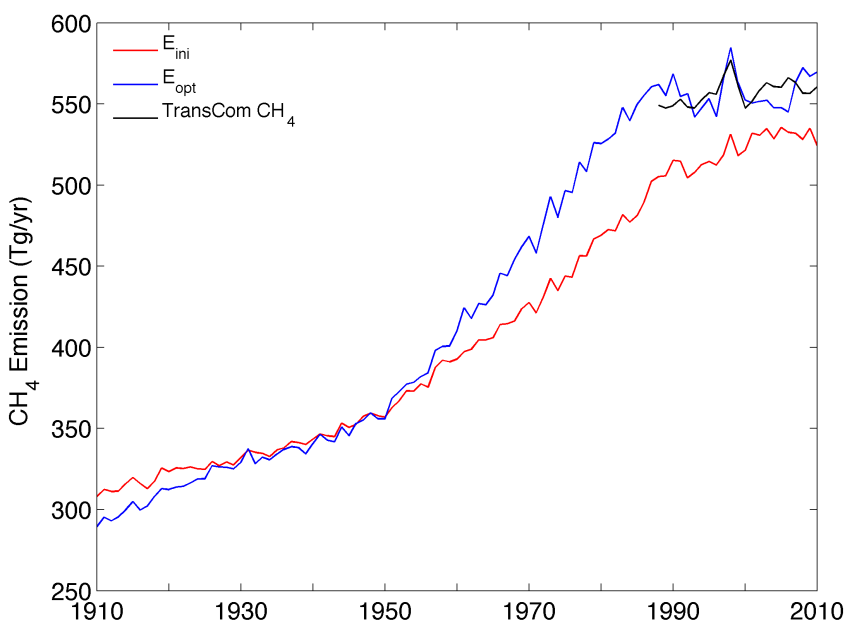

Figure 4. Time series of initial $\left(E_{\text {ini }}\right)$ and optimized $\left(E_{\text {opt }}\right)$ emissions. Emissions for a shorter period from the TransCom- $\mathrm{CH}_{4}$ experiment (Patra et al., 2011) are also shown for a comparison.

of observed $\mathrm{CH}_{4}$ concentration is limited to 1945-2010. Uncertainty in the IPD before direct measurements is of order $20 \mathrm{ppb}(1-\sigma)$, as indicated by the vertical uncertainty bars on the 20-year mean values (filled circles in Fig 5). This uncertainty in IPDs is consistent with that arising from the uncertainty (about 1.5 years) in effective age estimation of firn air, considering that $\mathrm{CH}_{4}$ growth rates were varying between $7-15 \mathrm{ppb}$ in the period of 1950-1990. The ACTM simulation with $E_{\text {ini }}$ generally underestimated the observed $\mathrm{CH}_{4}$ IPD, and statistically significantly for the period 1970-2011. This underestimation reduces significantly (Fig. 5, refer to the black and blue lines) when the global total emission is optimized $\left(E_{\text {opt }}\right)$ using observations from the Antarctic region. This suggests that the northern-southern hemispheric totals of $\mathrm{CH}_{4}$ emissions in $E_{\text {ini }}$ were incorrect, particularly for the period of 1970-2011. We assumed that the other factors affecting the IPD of $\mathrm{CH}_{4}$ concentration such as the latitudinal distribution of $\mathrm{CH}_{4}$ sinks and the mixing rates between hemispheres remained unchanged. Considering these uncertainties, we conclude that the ACTM simulations using $E_{\text {opt }}$ successfully reproduce the observed $\mathrm{CH}_{4}$ IPD during 1950-2011. We found a high correlation $(R=0.99)$ between differences of IPDs (IPD ${ }_{\text {opt }}-$ IPD $\left._{\text {int }}\right)$ and difference of NHSH emissions $\left(\Delta \mathrm{ENS}_{\mathrm{opt}}-\Delta \mathrm{ENS}_{\mathrm{int}}\right)$ in optimized and initial guess cases (Fig. 5 inset), i.e. the larger the change in difference of NH-SH emissions, the larger the change in IPD. The change in latitudinal distribution of emissions is the dominant driver of IPD, which is in agreement with a previous study (Mitchell et al., 2013).

\subsection{Application of $\delta^{13} \mathrm{C}$ for separation of source category in $\Delta E$}

The difference between initial and optimized emissions $\left(\Delta E=E_{\mathrm{opt}}-E_{\mathrm{int}}\right)$ ranges from -15 to 0 and from 0 


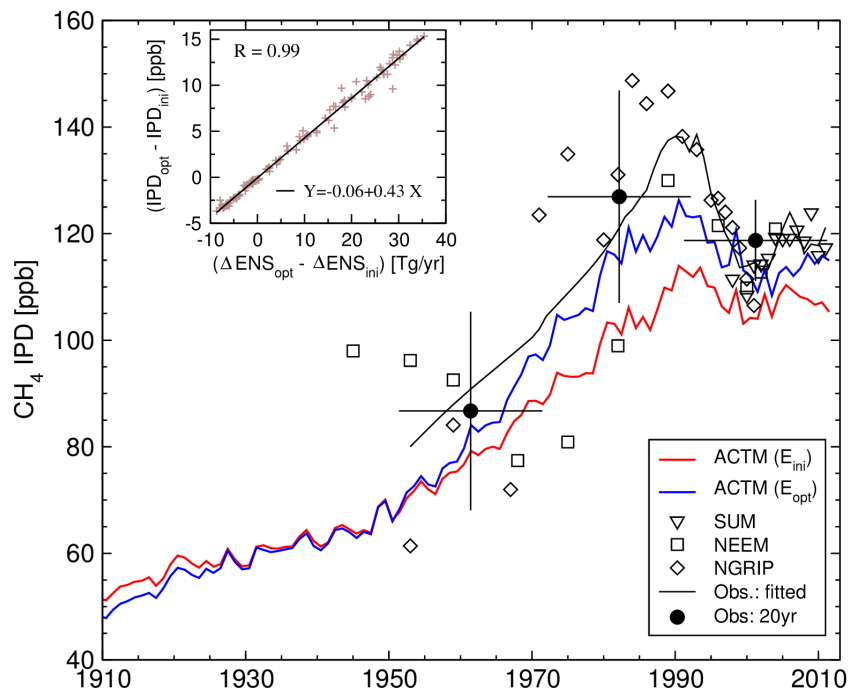

Figure 5. Comparison of model simulated (blue and red lines) and observed (symbols, square) inter-polar differences (IPD) of $\mathrm{CH}_{4}$ concentration. The black line is obtained by spline fitting the ice core observations from the Arctic and Antarctic regions (ref. Fig. 2). Also shown are the 20-year mean $\mathrm{CH}_{4}$ IPDs (filled circle), 1- $\sigma$ standard deviations (vertical bar) and 20-year range for averaging (horizontal bar). Inset: correlation between difference of IPD (IPD opt $_{-}$IPD $\left._{\text {int }}\right)$ and difference of NH-SH emissions $\left(\Delta \mathrm{ENS}_{\mathrm{opt}}-\Delta \mathrm{ENS}_{\mathrm{int}}\right)$ in optimized and initial guess cases.

to $60 \mathrm{Tg} \mathrm{yr}^{-1}$ for the first and second halves of the last 100 years, respectively (Fig. 4). Though $E_{\text {opt }}$ reproduces the $\mathrm{CH}_{4}$ concentration for the last 100 years fairly well, it does not verify how individual source categories have evolved over the period. Here we constrain different emission categories based on evolution of $\delta^{13} \mathrm{C}$ by separating $\Delta E$ into isotopically lighter and heavier sources (Sect. 2.6). We set the goal here to infer trends in emissions from biomass burning, because this emission category was kept constant over the whole simulation period due to the lack of consensus among different estimations (Mieville et al., 2010; Ito and Penner, 2005). The detailed interannual variability cannot be calculated from $\delta^{13} \mathrm{C}_{\text {atmos }}$ over the Antarctic region, because a smoothed fitted curve is used to interpolate between observations. For the sake of consistency, we also fitted smoothed curves for $\delta^{13} \mathrm{C}_{E_{\mathrm{opt}}}$ and $\Delta E$, and then redistributed the smoothed $\Delta E$ between $\Delta E_{1}$ and $\Delta E_{\mathrm{h}}$. Observations and smooth time series of $\delta^{13} \mathrm{C}_{\mathrm{atmos}}$ and $\delta^{13} \mathrm{C}_{E_{\mathrm{opt}}}$ are shown in Fig. 6a. We assumed $\delta^{13} \mathrm{C}_{\Delta E_{1}}$ and $\delta^{13} \mathrm{C}_{\Delta E_{\mathrm{h}}}$ values of $-60 \%$ (representing biogenic sources) and $-21.8 \%$ o (representing biomass burning emissions), respectively (Table 1). The corrected biomass burning emission now becomes $E_{\mathrm{bb}}=49.7$ (initial biomass burning emission) $+\Delta E_{\mathrm{h}}$ (correction term) $\mathrm{Tg} \mathrm{yr}^{-1}$. We have taken this approach because the level of confidence for estimations of emission variations from biomass burning is relatively low compared to all other emission categories, which are either estimated

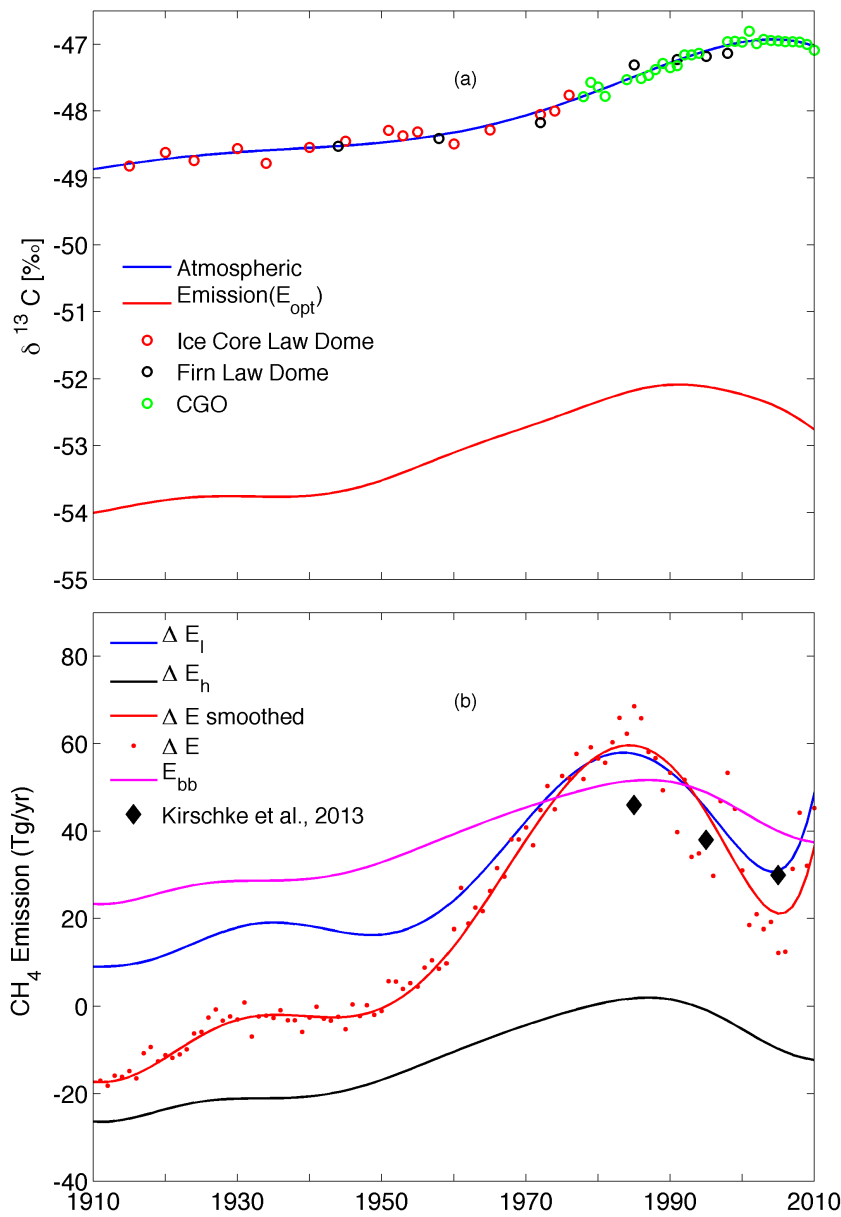

Figure 6. (a) Observations (circles) and smooth time series of $\delta^{13} \mathrm{C}_{\text {atmos }}$ and $\delta^{13} \mathrm{C}_{\text {Eopt }}$ (b) $\Delta E$ (smoothed) is split into $\Delta E_{1}$ and $\Delta E_{\mathrm{h}}$. Here $\delta^{13} \mathrm{C}_{\Delta E_{1}}$ and $\delta{ }^{13} \mathrm{C}_{\Delta E_{\mathrm{h}}}$ are assumed to be $-60 \%$ (biogenic sources, a supplementary source) and $-21.8 \%$ (biomass burning emission), respectively. Annual average $\delta^{13} \mathrm{C}_{\text {atmos }}$ observations from Law Dome (ice core (red circle)/firn air (blue circle) records) and CGO (air archive samples and NOAA-ESRL network direct observations; (magenta circle)) are shown separately here. The estimated biomass burning emission is given by $E_{\mathrm{bb}}=49.7$ (initial biomass burning emission) $+\Delta E_{\mathrm{h}}$ (correction term) $\mathrm{Tg} \mathrm{yr}^{-1}$. A recent estimation of biomass burning emissions (Kirschke et al., 2013) for last three decades is also shown for comparison (filled diamond).

based on statistical data of human activities or model simulations. $E_{\mathrm{bb}}$ is also shown in Fig. $6 \mathrm{~b} . E_{\mathrm{bb}}$ has an increasing trend (varies from 23 to $51 \mathrm{Tg} \mathrm{yr}^{-1}$ ) during the period 1910 1990 , followed by a decreasing trend (from 51 to $38 \mathrm{Tg} \mathrm{yr}^{-1}$ ) from the 1990s onward.

The $\mathrm{CO}$ based reference for open biomass burning by Ito et al. (2005), which is scaled using the ratio of $\mathrm{CH}_{4}$ and $\mathrm{CO}$ emissions from biomass burning based on the Global Inventory for Chemistry-Climate studies (GICC) data set (Mieville et al., 2010), shows a similar increasing trend. However, both 
the trend and mean values in the present study are larger than the GICC data set. The variation in biomass burning emissions during the 20th century is influenced by both the warmer climate and human activities (e.g. agricultural expansion, land-use change, domestic fuel use, fire management). The human population increased at the fastest rate since 1950 as per the United Nations statistics. However, saturation in cropland expansion in Asia, shift in domestic fuel use and improved fire management practices since the late 1980s would have suppressed the growth of $\mathrm{CH}_{4}$ emissions due to biomass burning caused by human activities ( $\mathrm{Pa}-$ tra et al., 2013; Li et al., 2002; Hurtt et al., 2006; Sathaye and Tyler, 1991; Montiel and Kraus, 2010). Uncertainties remain in the estimation of biomass burning emissions for the 20th century due to assumptions of $\delta^{13} C_{E_{i}}$ and $\alpha_{i}$ values. However, a sensitivity analysis using the estimated biomass burning emissions by varying $\delta^{13} \mathrm{C}_{\Delta E_{1}}$ from -55 to $-65 \%$ o (Sapart et al., 2012) suggests the trends in $\mathrm{CH}_{4}$ emissions from biomass burning are robust and only the magnitude of this emission could change by $\pm(5-15) \%$ (Appendix A). The decreasing trend in biomass burning emission has also been reported for recent years but typically at lower absolute levels (Fig. 6) (e.g. Kirschke et al., 2013). The inclusion of $\delta^{13} \mathrm{C}$ in inversions and global mass balances has also in the past yielded higher emissions for global biomass burning than inventories (Miller et al., 2002; Bousquet et al., 2006).

The supplement biogenic source $\left(\Delta E_{1}\right)$ follows a similar trend (a slow increasing trend during 1910-1950 and a rapid increase for the period 1950-1980, Fig. 6b) to that of the biogenic sources in the initial emissions $\left(E_{\text {ini }}\right)$ for the period 1910-1980 (Fig. 1a). Between 1981-2006 $\Delta E_{1}$ shows a decreasing trend, followed by an increase from 2007 onward (Fig. 6b), which is different from the biogenic sources in $E_{\text {ini }}$ showing an increasing trend during this whole period (Fig. 1a). Recent studies suggested a likely reduction in emissions from wetlands (e.g. due to more frequent El Niño events in the last three decades compared to the decades before 1980, Hodson et al., 2011, or due to the cooling effect of increased anthropogenic sulphur pollution, Gauci et al., 2004, or volcanic eruptions, Hogan et al., 1994) and changes in rice agricultural practices ( $\mathrm{Li}$ et al., 2002). The increase in atmospheric $\mathrm{CH}_{4}$ since 2007 may be ascribed to enhanced emissions from wetlands combined with an increasing trend of fossil fuel use (Dlugokencky et al., 2009; Bousquet et al., 2011; Kirschke et al., 2013; Bergamaschi et al., 2013). Apparently, $\Delta E_{1}$ is able to capture these detailed features of biogenic emissions in recent decades, which are otherwise different in $E_{\text {ini }}$. On the contrary, the rapid increase in emissions during 1950-1980, which is reflected in both $\Delta E_{1}$ and biogenic sources in $E_{\text {ini }}$, is likely to be driven by increasing anthropogenic activities (e.g. agriculture, ruminants and termites, organic waste deposits etc.) related to increasing human population during this period.

The present analysis limits the unaccounted emissions $\Delta E$ to only be from biomass burning (heavy) and biogenic (light) sources, but there could be other combinations of different categories of emissions. As we have two Eqs. (12) and (13), unique solutions are only possible for two unknown categories of emissions assuming the rest of the emissions are all known. One reasonable scenario is distributing $\Delta E$ into biomass burning and biogenic sources as examined in this study. To calculate for other possible combinations, such as fossil fuel (heavy) and biogenic (light) sources, we need to know the correct biomass burning emissions in $E_{\text {ini }}$ and leave the correction terms $\Delta E_{1}$ and $\Delta E_{\mathrm{h}}$ uncertain. We also attempted a combination of biomass burning and fossil fuel sources, but it produced unrealistic emission values (negative). We need additional constraints such as the ${ }^{14} \mathrm{C}$ (Lassey et al., 2007b) and hydrogen isotopic ratio $(\delta D)$ of $\mathrm{CH}_{4}$, which are presently very limited, to find solutions for more than two variables, e.g. distributing $\Delta E$ among biomass burning, fossil fuel and biogenic sources.

\section{Conclusions}

We have simulated $\mathrm{CH}_{4}$ concentration and its $\delta^{13} \mathrm{C}$ for 1910 2010. The major findings of our study are as follows:

1. We used initial emissions $\left(E_{\mathrm{ini}}\right)$ from bottom-up inventories for anthropogenic sources, emissions from wetlands and rice paddies simulated by a terrestrial biogeochemical model (VISIT), and the ACTM to simulate atmospheric $\mathrm{CH}_{4}$ concentrations for the period 19102010. By minimizing the difference between ACTM simulations and observed $\mathrm{CH}_{4}$ concentrations (over the Antarctic region) using a mass balance calculation, we estimated the optimized global emission $\left(E_{\mathrm{opt}}\right)$ for atmospheric $\mathrm{CH}_{4}$ for the past 100 years. The ACTM simulation with the optimized emissions reproduced the moderate $\left(5 \mathrm{ppbyr}^{-1}\right)$ and rapid (14.3 $\mathrm{ppb} \mathrm{yr}^{-1}$ ) growth rates for 1910-1950 and 1950-1990, respectively, and the drop in growth rate $\left(5.3 \mathrm{ppbyr}^{-1}\right)$ during the $1990 \mathrm{~s}$, near-steady state in the early 2000s, and the regrowth in 2007 (5.2 $\mathrm{ppb} \mathrm{yr}^{-1}$ ) fairly well. However, the ACTM underestimated IPDs, particularly for the period before the 1990s compared to the last 2 decades. Such underestimation in IPD can be corrected by increasing the $\mathrm{NH}-\mathrm{SH}$ gradient in the optimized emission $\left(E_{\mathrm{opt}}\right)$, suggesting that the change in latitudinal distribution of $\mathrm{CH}_{4}$ emissions is the dominant driver of IPD.

2. To further investigate the strength and variability of different $\mathrm{CH}_{4}$ emission categories, we introduced an additional constraint from $\delta^{13} \mathrm{C}$. This helps us to infer the possible trends in biomass burning emissions, which was initially kept constant over the period. The optimized result suggests an increasing biomass burning emissions until 1990 and a decrease afterwards. These variations are comparable with biomass burning emissions previously reported in the literature. We also esti- 
mated a supplementary biogenic source, which is likely to fill the incomplete information of biogenic sources in the initial emissions. Further details about $\mathrm{CH}_{4}$ sources could not be inferred due to limited observations covering the past 100 years and without measurements of additional constraints on $\mathrm{CH}_{4}$ source categories, such as the ${ }^{14} \mathrm{C}$ and $\delta D$. 


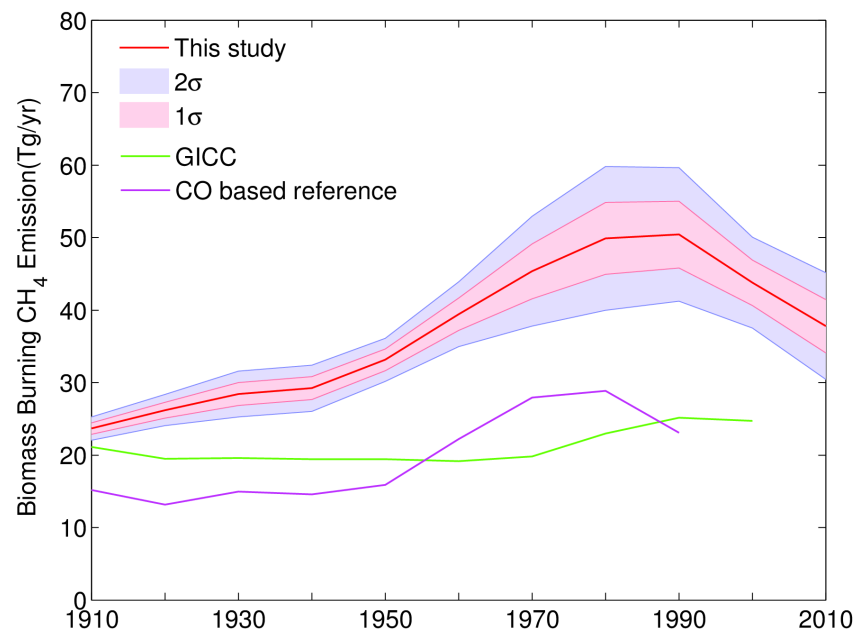

Figure A1. Sensitivity of estimated proposed biomass burning emissions with respect to varying $\delta^{13} \mathrm{C}_{\Delta E_{1}}$ (biogenic sources) from -55 to $-65 \%$.

\section{Appendix A}

As the splitting of $\Delta E$ into $\Delta E_{1}$ and $\Delta E_{\mathrm{h}}$ depends on the values of $\delta^{13} \mathrm{C}_{\Delta E_{1}}$ used in the calculation, a sensitivity of estimated proposed biomass burning emission with respect to varying $\delta^{13} C_{\Delta E_{1}}$, from -55 to $-65 \%$ (Sapart et al., 2012), is shown in Fig. A1. Here the estimated biomass burning emission is expressed as a decadal mean so that it is consistent with other data sets (GICC: Mieville et al., 2010; CO based reference: Ito et al., 2005). The uncertainty in estimation of possible biomass burning emissions increases from 1950 onward, reaching a peak in the 1990s. 


\section{The Supplement related to this article is available online at doi:10.5194/acp-15-2595-2015-supplement.}

Acknowledgements. This research is financially supported by the Green Network of Excellence (GRENE) Project by the Ministry of Education, Culture, Sports, Science and Technology (MEXT), Japan. We also acknowledge data centres/contributors Tohoku University, Japan; NOAA/ESRL air sampling network; GAGE/AGAGE network; NOAA's National Climate Data Center (NCDC); World Data Centre for Greenhouse Gases (WDCGG); Carbon Dioxide Information Analysis Center (CDIAC), US Department of Energy; the Australian Bureau of Meteorology/Cape Grim Baseline Air Pollution Station; Commonwealth Scientific and Industrial Research Organisation (CSIRO), Australia for the data set used in the present study. CSIRO's contribution was supported in part by the Australian Climate Change Science Program, an Australian Government Initiative.

Edited by: M. Heimann

\section{References}

Aoki, S., Nakazawa, T., Murayama, S., and Kawaguchi, S.: Measurements of atmospheric methane at the Japanese Antarctic Station, Syowa, Tellus B, 44, 273-281, 1992.

Arakawa, A. and Schubert, W. H.: Interactions of cumulus cloud ensemble with the large-scale environment, Part I, J. Atmos. Sci., 31, 671-701, 1974.

Bergamaschi P., Houweling, S., Segers, A., Krol, M., Frankenberg, C., Scheepmaker, R., Dlugokencky, E., Wofsy, S., Kort, E., Sweeney, C., Schuck, T., Brenninkmeijer, C., Chen, H., Beck, V., and Gerbig, C.: Atmospheric $\mathrm{CH}_{4}$ in the first decade of the 21st century: inverse modeling analysis using SCIAMACHY satellite retrievals and NOAA surface measurements, J. Geophys. Res.Atmos., 118, 7350-7369, doi:10.1002/jgrd.50480, 2013.

Bousquet, P., Ciais, P., Miller, J. B., Dlugokencky, E. J., Hauglustaine, D. A., Prigent, C., Van der Werf, G. R., Peylin, P., Brunke, E. G., Carouge, C., Langenfelds, R. L., Lathiere, J., Papa, F., Ramonet, M., Schmidt, M., Steele, L. P., Tyler, S. C., and White, J.: Contribution of anthropogenic and natural sources to atmospheric methane variability, Nature, 443, 439-443, doi:10.1038/nature05132, 2006.

Bousquet, P., Ringeval, B., Pison, I., Dlugokencky, E. J., Brunke, E.G., Carouge, C., Chevallier, F., Fortems-Cheiney, A., Frankenberg, C., Hauglustaine, D. A., Krummel, P. B., Langenfelds, R. L., Ramonet, M., Schmidt, M., Steele, L. P., Szopa, S., Yver, C., Viovy, N., and Ciais, P.: Source attribution of the changes in atmospheric methane for 2006-2008, Atmos. Chem. Phys., 11, 3689-3700, doi:10.5194/acp-11-3689-2011, 2011.

Buizert, C., Martinerie, P., Petrenko, V. V., Severinghaus, J. P., Trudinger, C. M., Witrant, E., Rosen, J. L., Orsi, A. J., Rubino, M., Etheridge, D. M., Steele, L. P., Hogan, C., Laube, J. C., Sturges, W. T., Levchenko, V. A., Smith, A. M., Levin, I., Conway, T. J., Dlugokencky, E. J., Lang, P. M., Kawamura, K., Jenk, T. M., White, J. W. C., Sowers, T., Schwander, J., and
Blunier, T.: Gas transport in firn: multiple-tracer characterisation and model intercomparison for NEEM, Northern Greenland, Atmos. Chem. Phys., 12, 4259-4277, doi:10.5194/acp-12-42592012, 2012.

Cantrell, C. A., Shetter, R. E., McDaniel, A. H., Calvert, J. G., Davidson, J. A., Lowe, D. C., Tyler, S. C., Cicerone, R. J., and Greenberg, J. P.: Carbon kinetic isotope effect in the oxidation of methane by hydroxyl radicals, J. Geophys. Res., 95, 2245522462, 1990.

Cao, M., Gregson, K., and Marshall, S.: Global methane emission from wetlands and its sensitivity to climate change, Atmos Environ., 32, 3293-3299, doi:10.1016/S1352-2310(98)00105-8, 1998.

Chappellaz, J. A., Fung, I. Y., and Thompson, A. M.: The atmospheric $\mathrm{CH}_{4}$ increase since the last glacial maximum, 1, Source estimates, Tellus B, 45, 228-241, 1993.

Cicerone, R. J. and Oremland, R. S.: Biogeochemical aspects of atmospheric methane, Global Biogeochem. Cy., 2, 299-327, 1988.

Colella, P. and Woodward, P. R.: The Piecewise Parabolic Method (PPM) for Gas-Dynamic Simulations, J. Comput. Phys., 54, 174 201, 1984.

Craig, H.: Isotopic standards for carbon and oxygen and correction factors for mass spectrometric analysis of carbon dioxide, Geochim. Cosmochim. Ac., 12, 133-149, 1957.

Cunnold, D. M., Steele, L. P., Fraser, P. J., Simmonds, P. G., Prinn, R. G., Weiss, R. F., Porter, L. W., O’Doherty, S., Langenfelds, R. L., Krummel, P. B., Wang, H. J., Emmons, L., Tie, X. X., and Dlugokencky, E. J.: In situ measurements of atmospheric methane at GAGE/AGAGE sites during 1985-2000 and resulting source inferences, J. Geophys. Res.-Atmos., 107, 4225, doi:10.1029/2001JD001226, 2002.

Davidson, J. A., Cantrell, C. A., Tyler, S. C., Shetter, R. E., Cicerone, R. J., and Calvert, J. G.: Carbon kinetic isotope effect in the reaction of $\mathrm{CH}_{4}$ with HO, J. Geophys. Res., 92, 2195-2199, 1987.

Dlugokencky, E. J., Masaire, K. A., Lang, P. M., Tans, P. P., Steele, L. P., and Nisbet, E. G.: A dramatic decrease in the growth rate of atmospheric methane in the Northern Hemisphere during 1992, Geophys. Res. Lett., 21, 45-48, 1994.

Dlugokencky, E. J., Houweling, S., Bruhwiler, L., Masarie, K. A., Lang, P. M., Miller, J. B., and Tans, P. P.: Atmospheric methane levels off: temporary pause or a new steady-state?, Geophys. Res. Lett., 30, 1992, doi:10.1029/2003GL018126, 2003.

Dlugokencky, E. J., Myers, R. C., Lang, P. M., Masarie, K. A., Crotwell, A. M., Thoning, K. W., Hall, B. D., Elkins, J. W., and Steele, L. P.:, Conversion of NOAA atmospheric dry air $\mathrm{CH}_{4}$ mole fractions to a gravimetrically prepared standard scale, J. Geophys. Res., 110, D18306, doi:10.1029/2005JD006035, 2005.

Dlugokencky, E. J., Bruhwiler, L., White, J. W. C., Emmons, L. K., Novelli, P. C., Montzka, S. A., Masarie, K. A., Lang, P. M., Crotwell, A. M., Miller, J. B., and Gatti, L. V.: Observational constraints on recent increases in the atmospheric $\mathrm{CH}_{4}$ burden, Geophys. Res. Lett., 36, L18803, doi:10.1029/2009GL039780, 2009.

Dlugokencky, E. J., Nisbet, E. G., Fisher, R., and Lowry, D.,: Global atmospheric methane: budget, changes and dangers, Philos. T. R. Soc. A, 369, 2058-2072, 2011.

Etheridge, D. M., Steele, L. P., Francey, R. J., and Langenfelds, R. L.: Atmospheric methane between 1000 A. D., 
and present: evidence of anthropogenic emissions and climatic variability, J. Geophys. Res., 103, 15979-15993, doi:10.1029/98JD00923, 1998.

Etiope, G. and Milkov, A. V.: A new estimate of global methane flux from onshore and shallow submarine mud volcanoes to the atmosphere, Environ. Geol., 46, 997-1002, doi:10.1007/s00254004-1085-1, 2004.

Ferretti, D. F., Miller, J. B., White, J. W. C., Etheridge, D. M., Lassey, K. R., Lowe, D. C., MacFarling Meure, C. M., Dreier, M. F., Trudinger, C. M., van Ommen, T. D., and Langenfelds, R. L.: Unexpected changes to the global methane budget over the past 2000 years, Science, 309, 1714-1717, doi:10.1126/science.1115193, 2005.

Francey, R. J., Manning, M. R., Allison, C. E., Coram, S. A., Etheridge, D. M., Langenfelds, R. L., Lowe, D. C., and Steele, L. P.: A history of $\delta^{13} \mathrm{C}$ in atmospheric $\mathrm{CH}_{4}$ from the Cape Grim Air Archive and Antarctic firn air, J. Geophys. Res., 104, 23631-23643, doi:10.1029/1999JD900357, 1999.

Fung, I., John, J., Lerner, J., Matthews, E., Prather, M., Steele, L. P., and Fraser, P. J.: Three-dimensional model synthesis of the global methane cycle, J. Geophys. Res., 96, 13033-13065, doi:10.1029/91JD01247, 1991.

Gauci V, Matthews, E., Dise, N., Walter, B., Koch, D., Granberg, G., and Vile, M. A.: Sulfur pollution suppression of the wetland methane source in the 20th and 21st centuries, Proc. Natl. Acad. Sci. USA 101, 12583-12587, 2004.

Gupta, M. L., McGrath, M. P., Cicerone, R. J., Rowland, F. S., and Wolfsberg, M.: ${ }^{12} \mathrm{C} /{ }^{13} \mathrm{C}$ kinetic isotope effects in the reactions of $\mathrm{CH}_{4}$ with $\mathrm{OH}$ and $\mathrm{Cl}$, Geophys. Res. Lett., 24, 2761-2764, 1997.

Hansen, J., Ruedy, R., Sato, M., and Lo, K.: Global surface temperature change, Rev. Geophys., 48, RG4004, doi:10.1029/2010RG000345, 2010.

Hasumi, H., Emori, S., Abe-Ouchi, A., et al., K-1 Coupled GCM (MIROC) Description, Technical report, CCSR, Kashiwa, Chiba, Japan, 2004.

Hodson, E. L., Poulter, B., Zimmermann, N. E., Prigent, C., and Kaplan, J. O.: The El Niño-Southern Oscillation and wetland methane interannual variability, Geophys. Res. Lett., 38, L08810, doi:10.1029/2011GL046861, 2011.

Hogan, K. B. and Harriss, R. C.: Comment on "A dramatic decrease in the growth rate of atmospheric methane in the Northern Hemisphere during 1992" by E. J. Dlugokencky et al., Geophys. Res. Lett., 21, 2445-2446, doi:10.1029/94GL02601, 1994.

Hou, S., Chappellaz, J., Raynaud, D., Masson-Delmotte, V., Jouzel, J., Bousquet, P., and Hauglustaine, D.: A new Himalayan ice core $\mathrm{CH}_{4}$ record: possible hints at the preindustrial latitudinal gradient, Clim. Past, 9, 2549-2554, doi:10.5194/cp-9-25492013, 2013.

Houweling, S., van der Werf, G. R., Klein Goldewijk, K., Röckmann, T., and Aben, I.: Early anthropogenic $\mathrm{CH}_{4}$ emissions and the variation of $\mathrm{CH}_{4}$ and ${ }^{13} \mathrm{CH}_{4}$ over the last millennium, Global Biogeochem. Cy., 22, GB1002, doi:10.1029/2007GB002961, 2008.

Hurtt, G. C., Frolking, S., Fearon, M. G., Moore, B., Shevliakova, E., Malyshev, S., Pacala, S. W., and Houghton, R. A.: The underpinnings of land-use history: three centuries of global gridded land-use transitions, wood-harvest activity, and resulting secondary lands, Glob. Change Biol., 12, 1-22, 2006.

Ishijima, K., Sugawara, S., Kawamura, K., Hashida, G., Morimoto, S., Murayama, S., Aoki, S., and Nakazawa, T.: Temporal variations of the atmospheric nitrous oxide concentration and its $\mathrm{d} 15 \mathrm{~N}$ and $\mathrm{d} 18 \mathrm{O}$ for the latter half of the 20th century reconstructed from firn air analyses, J. Geophys. Res., 112, D03305, doi:10.1029/2006JD007208, 2007.

Ito, A. and Inatomi, M.: Use of a process-based model for assessing the methane budgets of global terrestrial ecosystems and evaluation of uncertainty, Biogeosciences, 9, 759-773, doi:10.5194/bg9-759-2012, 2012.

Ito, A. and Penner, J. E.: Historical emissions of carbonaceous aerosols from biomass and fossil fuel burning for the period 1870-2000, Global Biogeochem. Cy., 19, GB2028, doi:10.1029/2004GB00237, 2005.

John, J. G., Fiore, A. M., Naik, V., Horowitz, L. W., and Dunne, J. P.: Climate versus emission drivers of methane lifetime against loss by tropospheric OH from 1860-2100, Atmos. Chem. Phys., 12, 12021-12036, doi:10.5194/acp-12-12021-2012, 2012.

Jones, R. L. and Pyle, J. A.: Observations of $\mathrm{CH}_{4}$ and $\mathrm{N}_{2} \mathrm{O}$ by the Nimbus-7 SAMS: a comparison with in situ data and twodimensional numerical model calculations. J. Geophys. Res., 89, 5263-5279, 1984.

Kirschke, S., Bousquet, P., Ciais, P., Saunois, M., Canadell, J. G., Dlugokencky, E. J., Bergamaschi, P., Bergmann, D., Blake, D. R., Bruhwiler, L., Cameron-Smith, P., Castaldi, S., Chevallier, F., Feng, L., Fraser, A., Heimann, M., Hodson, E. L., Houweling, S., Josse, B., Fraser, P. J., Krummel, P. B., Lamarque, J.-F., Langenfelds, R. L., Le Quere, C., Naik, V., O’Doherty, S., Palmer, P. I., Pison, I., Plummer, D., Poulter, B., Prinn, R. G., Rigby, M., Ringeval, B., Santini, M., Schmidt, M., Shindell, D. T., Simpson, I. J., Spahni, R., Steele, L. P., Strode, S. A., Sudo, K., Szopa, S., van der Werf, G. R., Voulgarakis, A., van Weele, M., Weiss, R. F., Williams, J. E., and Zeng, G.: Three decades of global methane sources and sinks, Nat. Geosci., 6, 813-823, doi:10.1038/ngeo1955, 2013.

Krol, M. and Lelieveld, J.: Can the variability in tropospheric $\mathrm{OH}$ be deduced from measurements of 1,1,1-trichloroethane (methyl chloroform)?, J. Geophys. Res., 108, 4125, doi:10.1029/2002JD002423, 2003.

Lamarque, J.-F., Bond, T. C., Eyring, V., Granier, C., Heil, A., Klimont, Z., Lee, D., Liousse, C., Mieville, A., Owen, B., Schultz, M. G., Shindell, D., Smith, S. J., Stehfest, E., Van Aardenne, J., Cooper, O. R., Kainuma, M., Mahowald, N., McConnell, J. R., Naik, V., Riahi, K., and van Vuuren, D. P.: Historical (1850-2000) gridded anthropogenic and biomass burning emissions of reactive gases and aerosols: methodology and application, Atmos. Chem. Phys., 10, 7017-7039, doi:10.5194/acp10-7017-2010, 2010.

Lambert, G. and Schmidt, S.: Reevaluation of the oceanic flux of methane: uncertainties and long term variations, Chemosph. Global Change Sci., 26, 579-589, 1993.

Lassey, K. R., Lowe, D. C., and Manning, M. R.: The trend in atmospheric methane $\delta^{13} \mathrm{C}$ and implications for isotopic constraints on the global methane budget, Global Biogeochem. Cy., 14, 4149, 2000 .

Lassey, K. R., Etheridge, D. M., Lowe, D. C., Smith, A. M., and Ferretti, D. F.: Centennial evolution of the atmospheric methane bud- 
get: what do the carbon isotopes tell us?, Atmos. Chem. Phys., 7, 2119-2139, doi:10.5194/acp-7-2119-2007, 2007a.

Lassey, K. R., Lowe, D. C., and Smith, A. M.: The atmospheric cycling of radiomethane and the "fossil fraction" of the methane source, Atmos. Chem. Phys., 7, 2141-2149, doi:10.5194/acp-72141-2007, 2007b.

Li, C., Qiu, J., Frolking, S., Xiao, X., Salas, W., Moore III, B., Boles, S., Huang, Y., and Sass, R.: Reduced methane emissions from largescale changes in water management of China's rice paddies during 1980-2000, Geophys. Res. Lett., 29, 1972, doi:10.1029/2002GL015370, 2002.

Lin, S.-J. and Rood, R.: Multidimensional flux-form semiLagrangian transport schemes, Mon. Weather Rev., 124, 20462070, 1996.

Loulergue, L., Schilt, A., Spahni, R., Masson-Delmotte, V., Blunier, T., Lemieux, B., Barnola, J.-M., Raynaud, D., Stocker, T. F., and Chappellaz. J.: Orbital and millennial-scale features of atmospheric $\mathrm{CH}_{4}$ over the past 800,000 years, Nature, 453, 383-386, 2008.

MacFarling Meure, C., Etheridge, D., Trudinger, C., Steele, P., Langenfelds, R., van Ommen, T., Smith, A., and Elkins, J. W.: Law Dome $\mathrm{CO}_{2}, \mathrm{CH}_{4}$ and $\mathrm{N}_{2} \mathrm{O}$ ice core records extended to 2000 years BP, Geophys. Res. Lett., 33, L14810, doi:10.1029/2006GL026152, 2006.

Mellor, G. L. and Yamada, T.: A hierarchy of turbulence closure models for planetary boundary layers, J. Atmos. Sci., 31, 17911806, 1974.

Mieville, A., Granier, C., Liousse, C., Guillaume, B., Mouillot, F., Lamarque, J.-F., Grégoire, J.-M., and Pétron, G.: Emissions of gases and particles from biomass burning using satellite data and an historical reconstruction, Atmos. Environ., 44, 1469-1477, doi:10.1016/j.atmosenv.2010.01.011, 2010.

Miller, J. B., Mack, K. A., Dissly, R., White, J. W. C., Dlugokencky, E. J., and Tans, P. P.: Development of analytical methods and measurements of ${ }^{13} \mathrm{C} /{ }^{12} \mathrm{C}$ in atmospheric $\mathrm{CH}_{4}$ from the NOAA/CMDL global air sampling network, J. Geophys. Res., 107, ACH 11-1-ACH 11-15, doi:10.1029/2001JD000630, 2002.

Mitchell, L., Brook, E., Lee, J. E., Buizert, C., and Sowers, T.: Constraints on the Late Holocene anthropogenic contribution to the atmospheric methane budget, Science, 22, 964-966, doi:10.1126/science.1238920, 2013.

Montiel, C. and Kraus, D. (Eds.): Best Practices of Fire Use: Prescribed Burning and Suppression: Fire Programmes in Selected Case-study Regions in Europe, European Forest Institute, WS Bookwell Oy, Porvoo, Finland, Report 24, 169 pp., 2010.

Monteil, G., Houweling, S., Dlugockenky, E. J., Maenhout, G., Vaughn, B. H., White, J. W. C., and Rockmann, T.: Interpreting methane variations in the past two decades using measurements of $\mathrm{CH}_{4}$ mixing ratio and isotopic composition, Atmos. Chem. Phys., 11, 9141-9153, doi:10.5194/acp-11-9141-2011, 2011.

Montzka, S. A., Butler, J. H., Elkins, J. W., Thompson, T. M., Clarke, A. D., and Lock, L. T.: Present and future trends in the atmospheric burden of ozone-depleting halogens, Nature, 398, 690-694, 1999.

Myhre, G., Shindell, D., Bréon, F.-M., Collins, W. Fuglestvedt, J., Huang, J., Koch, D. Lamarque, J.-F., Lee, D., Mendoza, B., Nakajima, T., Robock, A., Stephens, G. Takemura, T., and Zhang, H.: Anthropogenic and natural radiative forcing, in: Climate Change 2013: The Physical Science Basis, Fifth Assess- ment Report of the Intergovernmental Panel on Climate Change, edited by: Stocker, T. F. et al., Cambridge University Press, Cambridge, UK, New York, NY, USA, 659-740, 2013.

Naik, V., Voulgarakis, A., Fiore, A. M., Horowitz, L. W., Lamarque, J.-F., Lin, M., Prather, M. J., Young, P. J., Bergmann, D., Cameron-Smith, P. J., Cionni, I., Collins, W. J., Dalsøren, S. B., Doherty, R., Eyring, V., Faluvegi, G., Folberth, G. A., Josse, B., Lee, Y. H., MacKenzie, I. A., Nagashima, T., van Noije, T. P. C., Plummer, D. A., Righi, M., Rumbold, S. T., Skeie, R., Shindell, D. T., Stevenson, D. S., Strode, S., Sudo, K., Szopa, S., and Zeng, G.: Preindustrial to present-day changes in tropospheric hydroxyl radical and methane lifetime from the Atmospheric Chemistry and Climate Model Intercomparison Project (ACCMIP), Atmos. Chem. Phys., 13, 5277-5298, doi:10.5194/acp13-5277-2013, 2013.

Nakazawa, T., Machida, T., Tanaka, M., Fujii, Y., Aoki, S., and Watanabe, O.: Differences of the atmospheric $\mathrm{CH}_{4}$ concentration between the Arctic and Antarctic regions in pre-industrial/preagricultural era, Geophys. Res. Lett., 20, 943-946, 1993.

Olivier, J. G. J. and J. J. M.: Global emissions sources and sinks, in: The Climate System, edited by: Berdowski, J., Guicherit, R., and Heij, B. J., A. A. Balkema Publishers/Swets \& Zeitlinger Publishers, Lisse, the Netherlands, ISBN 9058092550, 33-78, 2001.

Onogi, K., Tsutsui, J., Koide, H., Sakamoto, M., Kobayashi, S., Hatsushika, H. Matsumoto, T., Yamazaki, N., Kamahori, H., Takahashi, K., Kadokura, S., Wada, K., Kato, K., Oyama, R., Ose, T., Mannoji, N., and Taira, R.: The JRA-25 reanalysis, J. Meteorol. Soc. Jpn., 85, 369-432, 2007.

Patra, P. K., Takigawa, M., Dutton, G. S., Uhse, K., Ishijima, K., Lintner, B. R., Miyazaki, K., and Elkins, J. W.: Transport mechanisms for synoptic, seasonal and interannual $\mathrm{SF}_{6}$ variations and "age" of air in troposphere, Atmos. Chem. Phys., 9, 1209-1225, doi:10.5194/acp-9-1209-2009, 2009.

Patra, P. K., Houweling, S., Krol, M., Bousquet, P., Belikov, D., Bergmann, D., Bian, H., Cameron-Smith, P., Chipperfield, M. P., Corbin, K., Fortems-Cheiney, A., Fraser, A., Gloor, E., Hess, P., Ito, A., Kawa, S. R., Law, R. M., Loh, Z., Maksyutov, S., Meng, L., Palmer, P. I., Prinn, R. G., Rigby, M., Saito, R., and Wilson, C.: TransCom model simulations of $\mathrm{CH}_{4}$ and related species: linking transport, surface flux and chemical loss with $\mathrm{CH}_{4}$ variability in the troposphere and lower stratosphere, Atmos. Chem. Phys., 11, 12813-12837, doi:10.5194/acp-1112813-2011, 2011.

Patra, P. K., Ito, A., and Yan, X.: Climate change and agriculture in Asia: a case study for methane emission due to rice cultivation, in: Climate Change and Agriculture, edited by: Bhattacharyya, T., Pal, D. K., Sarkar, D., and Wani, S. P., Studium press (India) Pvt. Ltd., New Delhi, ISBN978-93-80012-40-7, 328 pp., 2013.

Patra, P. K., Krol, M. C., Montzka, S. A., Arnold, T., Atlas, E. L., Lintner, B. R., Stephens, B. B., Xiang, B., Elkins, J. W., Fraser, P. J., Ghosh, A., Hintsa, E. J., Hurst, D. F., Ishijima, K., Krummel, P. B., Miller, B. R., Miyazaki, K., Moore, F. L., Mühle, J., O’Doherty, S., Prinn, R. G., Steele, L. P., Takigawa, M., Wang, H. J., Weiss, R. F., Wofsy, S. C., and Young, D.: Observational evidence for interhemispheric hydroxyl parity, Nature, 513, 219223, 2014. 
Prinn, R. G., Weiss, R. F., Fraser, P. J., Simmonds, P. G., Cunnold, D. M., Alyea, F. N., O'Doherty, S., Salameh, P., Miller, B. R., Huang, J., Wang, R. H. J., Hartley, D. E., Harth, C., Steele, L. P., Sturrock, G., Midgley, P. M., and McCulloch, A.: A history of chemically and radiatively important gases in air deduced from ALE/GAGE/AGAGE, J. Geophys. Res., 105, 1775117792, doi:10.1029/2000JD900141, 2000.

Quay, P., Stutsman, J., Wilbur, D., Snover, A., Dlugokencky, E., and Brown, T.: The isotopic composition of atmospheric methane, Global Biogeochem. Cy., 13, 445-461, doi:10.1029/1998GB900006, 1999.

Rasmussen, R. A. and Khalil, M. A. K.: Atmospheric methane in the recent and ancient atmospheres: concentrations, trends, and interhemispheric gradient, J. Geophys. Res., 89, 11599-11605, doi:10.1029/JD089iD07p11599, 1984.

Rayner, N. A., Parker, D. E., Horton, E. B., Folland, C. K., Alexander, L. V., Rowell, D. P., Kent, E. C., and Kaplan, A.: Global analyses of sea surface temperature, sea ice, and night marine air temperature since the late nineteenth century, J. Geophys. Res., 108, 4407, doi:10.1029/2002JD002670, 2003.

Rigby, M., Prinn, R. G., Fraser, P. J., Simmonds, P. G., Langenfelds, R. L., Huang, J., Cunnold, D. M., Steele, L. P., Krummel, P. B., Weiss, R. F., O'Doherty, S., Salameh, P. K., Wang, H. J., Harth, C. M., Mühle, J., and Porter, L. W.: Renewed growth of atmospheric methane, Geophys. Res. Lett., 35, L22805, doi:10.1029/2008GL036037, 2008.

Rice, A. L., Tyler, S. C., McCarthy, M. C., Boering, K. A., and Atlas, E.: Carbon and hydrogen isotopic compositions of stratospheric methane: 1. High-precision observations from the NASA ER-2 aircraft, J. Geophys. Res., 108, 4460, doi:10.1029/2002JD003042, 2003.

Röckmann, T., Brass, M., Borchers, R., and Engel, A.: The isotopic composition of methane in the stratosphere: high-altitude balloon sample measurements, Atmos. Chem. Phys., 11, 13287-13304, doi:10.5194/acp-11-13287-2011, 2011.

Sander, S. P., Friedl, R. R., Golden, D. M., Kurylo, M. J., Moortgat, G. K., Keller-Rudek, H., Wine, P. H., Ravishankara, A. R., Kolb, C. E., Molina, M. J., Finlayson-Pitts, B. J., Huie, R. E., and Orkin, V. L.: Chemical Kinetics and Photochemical Data for Use in Atmospheric Studies, Evaluation Number 15, JPL Publication 06-2, Jet Propulsion Laboratory, Pasadena, CA, 2006.

Sapart, C. J., Monteil, G., Prokopiou, M., Van de Wal, R. S. W., Kaplan, J. O., Sperlich, P., Krumhardt, K. M., Van der Veen, C., Houweling, S., Krol, M. C., Blunier, T., Sowers, T., Martinerie, P., Witrant, E., Dahl-Jensen, D., and Röckmann, T.: Natural and anthropogenic variations in methane sources during the past two millennia, Nature, 490, 85-88, doi:10.1038/nature11461, 2012.

Sapart, C. J., Martinerie, P., Witrant, E., Chappellaz, J., van de Wal, R. S. W., Sperlich, P., van der Veen, C., Bernard, S., Sturges, W. T., Blunier, T., Schwander, J., Etheridge, D., and Röckmann, T.: Can the carbon isotopic composition of methane be reconstructed from multi-site firn air measurements?, Atmos. Chem. Phys., 13, 6993-7005, doi:10.5194/acp-13-6993-2013, 2013.

Sathaye, J. and Tyler, S.: Transitions in household energy use in urban China, India, the Philippines, Thailand and Hong Kong, Annu. Rev. Energ. Environ., 16, 295-335, 1991.
Saueressig, G., Bergamaschi, P., Crowley, J. N., Fischer, H., and Harris, G. W.: Carbon kinetic isotope effect in the reaction of $\mathrm{CH}_{4}$ With $\mathrm{Cl}$ atoms, Geophys. Res. Lett., 22, 1225-1228, 1995.

Saueressig, G., Crowley, J. N., Bergamaschi, P., Bruhl, C., Brenninkmeijer, C. A. M., and Fischer, H.: Carbon 13 and D kinetic isotope effects in the reactions of $\mathrm{CH}_{4}$ with $\mathrm{O}\left({ }^{1} \mathrm{D}\right)$ and $\mathrm{OH}$ : new laboratory measurements and their implications for the isotopic composition of stratospheric methane, J. Geophys. Res., 106, 23127-23138, 2001.

Schmitt, J., Seth, B., Bock, M., van der Veen, C., Möller, L., Sapart, C. J., Prokopiou, M., Sowers, T., Röckmann, T., and Fischer, H.: On the interference of $\mathrm{Kr}$ during carbon isotope analysis of methane using continuous-flow combustion-isotope ratio mass spectrometry, Atmos. Meas. Tech., 6, 1425-1445, doi:10.5194/amt-6-1425-2013, 2013.

Spivakovsky, C. M., Logan, J. A., Montzka, S. A., Balkanski, Y. J., Foreman-Fowler, M., Jones, D. B. A., Horowitz, L. W., Fusco, A. C., Brenninkmeijer, C. A. M., Prather, M. J., Wofsy, S. C., and McElroy, M. B.: Three-dimensional climatological distribution of tropospheric $\mathrm{OH}$ : update and evaluation, J Geophys. Res., 105, 8931-8980, doi:10.1029/1999JD901006, 2000.

Sugawara, S., Nakazawa, T., Shirakawa, Y., Kawamura, K., and Aoki, S.: Vertical profile of the carbon isotopic ratio of stratospheric methane over Japan, Geophys. Res. Lett., 24, 2989-2992, 1997.

Tanaka, N., Xiao, Y., and Lasaga, A. C.: Ab initio study on carbon kinetic isotope effect (KIE) in the reaction ofCH $4+\mathrm{Cl}$, J. Atmos. Chem., 23, 37-49, 1996.

Takigawa, M., Takahashi, M., and Akiyoshi, H.: Simulation of ozone and other chemical species using a Center for Climate System Research/National Institute for Environmental Studies atmospheric GCM with coupled stratospheric chemistry, J. Geophys., Res., 104, 14003-14018, 1999.

Trudinger, C. M., Etheridge, D. M., Rayner, P. J., Enting, I. G., Sturrock, G. A., and Langenfelds, R. L.: Reconstructing atmospheric histories from measurements of air composition in firn, J. Geophys. Res., 4780, doi:10.1029/2002JD002545, 2002.

Trudinger, C. M., Enting, I. G., Rayner, P. J., Etheridge, D. M., Buizert, C., Rubino, M., Krummel, P. B., Blunier T.: How well do different tracers constrain the firn diffusivity profile?, Atmos. Chem. Phys., 13, 1485-1510, doi:10.5194/acp-13-14852013, 2013.

Umezawa, T., Goto, D., Aoki, S., Ishijima, K., Patra, P. K., Sugawara, S., Morimoto, S., and Nakazawa, T.: Variations of tropospheric methane over Japan during 1988-2010, Tellus B, 66, 23837, doi:10.3402/tellusb.v66.23837, 2014.

van Aardenne, J. A., Dentener, F. J., Olivier, J. G. J., Klein Goldewijk, C. G. M., and Lelieveld, J.: A high resolution data set of historical anthropogenic trace gas emissions for the period 18901990, Global Biogeochem. Cy., 15, 909-928, 2001.

Wang, J. S., McElroy, M. B., Spivakovsky, C. M., and Jones, D. B. A.: On the contribution of anthropogenic $\mathrm{Cl}$ to the increase in $\mathrm{d}^{13} \mathrm{C}$ of atmospheric methane, Global Biogeochem. Cy., 16, 1047, doi:10.1029/2001GB001572, 2002.

White, J. W. C. and Vaughn, B. H.: University of Colorado, Institute of Arctic Alpine Research (INSTAAR), Stable Isotopic Composition of Atmospheric Methane $\left({ }^{13} \mathrm{C}\right)$ from the NOAA ESRL Carbon Cycle Cooperative Global Air Sampling Network, 1998- 
2011, Version: 2013-04-05, available at: ftp://ftp.cmdl.noaa.gov/ ccg/ch4c13/flask/event/ (last access: 5 April 2013), 2011. 